\title{
Az ember jogalanyiságának, életéhez és méltóságához való joga a kortárs katolikus természetjogi alapú jogfilozófiai megközelítésben
}

\section{FRIVALDSZKY JÁNOS ${ }^{1}$}

Az Emberi jogok egyetemes nyilatkozata megfogalmazása idöszakában nem tünt lehetségesnek, de szükségesnek sem azon emberi személy filozófiai antropológiai meghatározása, akinek jogait a dokumentum kinyilvánította. Manapság azonban ez elkerülhetetlen, mert sem az emberi jogalanyiság, sem a legalapvetöbb valódi emberi jogok nem jelenthetök ki, nem alapozhatók meg és nem is védhetök anélkül. Manapság ugyanis e jogokat sokszor, az uralkodó libertariánus és értékrelativista szellemi közegben, éppen a fogalmi megalapozás hiányában maga az ember ellen, annak jogalanyiságához, élethez és méltóságához való joga ellen fordítják. A katolikus természetjogi hagyomány nagy segitséget nyújtott mindig is e megalapozásban, miközben már újabb és újabb bioetikai helyzetekben kell védeni az emberi személyt legalapvetőbb jogain keresztül.

Kulcsszavak: alapvető emberi jogok, filozófiai antropológia, természetjog, emberi személy, emberi lélek, méltóság, emberi élet, jogalanyiság, jogképesség

\section{Legal Personality and Man's Right to Life and Human Dignity in Contemporary Catholic Natural Law Philosophy}

At the drafting time of the Universal Declaration of Human Rights, it seemed neither possible, nor necessary to establish a philosophical anthropological definition of the human person whose rights were proclaimed by the Declaration. Nowadays, this is, however, inevitable because neither human legal personality, nor the most fundamental and real human rights could be proclaimed, established, or enforced without it. For nowadays, when the intellectual milieu is governed by prevalent libertarian and value relativist ideas, these rights are, mostly due to the lack of their conceptual basis, often turned against the person himself, his right to legal personality, life and human dignity. The Catholic natural law tradition has, on the other hand,

1 Tanszékvezető egyetemi tanár, PPKE JÁK; e-mail: frivaldszky.janos@jak.ppke.hu 
always proved to be an effective aid in this process, when, through his rights, the human person is to be protected in ever new bioethical situations.

Keywords: basic human rights, philosophic anthropology, natural law, human person, human soul, human dignity, life of a human being, legal personality, legal capability

\section{Az emberi jogok megalapozási szükségességének problémája: az Emberi jogok egyetemes nyilatkozatának tanulsága}

Az emberi jogok jogilag kötelező erejűként való felismerése történelmi-erkölcsi tudatosodási folyamat eredménye volt. Azonban az emberi jogok e kötelező voltának fel- és elismerése nemcsak az emberi jogok alapjául szolgáló természeti törvény megismerésének fokozatosságára, vagyis annak episztemológiai oldalára bizonyíték, hanem arra is, hogy az ember történeti-társadalmi-kulturális lényként, azaz kulturális egzisztenciaként éli meg életét, vagyis nem elvont a priori meghatározható metafizikai lényegként, amelynek ismérvei - s így az azokból deduktíve fakadó emberi jogok is - egyszer és mindenkorra teljes mértékben meghatározhatók lennének. E felismerések az Emberi jogok egyetemes nyilatkozatának (Nyilatkozat) elfogadása időszakában erős nyomot hagytak az emberiség emberi jogokról való gondolkodásán. Olyannyira, hogy szinte már a másik végletbe esett a közgondolkodás, minthogy az emberi természetről, annak lényegéről s az azokból deduktív gondolkodással fakadó emberi jogokról szinte már nem is illik beszélni antiesszencialistának is nevezhető posztmodern korunkban.

Mi azonban úgy véljük, hogy azon törekvésekkel szemben, amelyek az említett Nyilatkozatban foglalt némely alapvető jogot és alapvető intézményt azok eredeti, a deklarációban foglaltakkal ellentétes jelentésadásokkal kívánják ideológiai és politikai okokból megtölteni, például az „abortuszhoz való jog” és a homoszexuális párok házasságkötéshez való jogának emberi jogként való igénybejelentései esetében, a továbbfejlesztés tekintetében pedig a szexuális és „reprodukciós” „emberi jogokért” küzdve, nos, ezen törekvésekkel szemben csak az emberi természeti lényegből logikai szükségszerűséggel fakadó jogokkal (az „abortuszhoz való joggal” szemben az élethez és a jogalanyisághoz való jog deduktív megalapozásával) és intézményekkel (a házasságnak egy férfi és egy nő intézményesített kapcsolataként való megalapozásával) lehet érvelni helyesen. ${ }^{2}$ Ezen érvelés érvényességi terepe nagyon szűkre szabott, hiszen

2 A felek által aláírt Nyilatkozatban foglalt jogokat vagy úgy tekintették, hogy saját nézetrendszerük szerint megalapozhatók filozófiailag vagy vallásilag, vagy úgy gondolták, hogy azok ilyen módon nem megalapozható, de általános érvényủ jogi követelések. Jacques Maritain úgy tartotta, hogy az aláíró felek egy olyan közös metafizikai nézetrendszert osztottak, amelynek nem voltak tudatában. Pusztán az egyetértés e ténye is mutatja azt, hogy a természeti törvény minden em- 
az emberi természetből fakadó lényegi ismérvekből vezet le logikai szükségszerüség adta szigorral néhány alapvető emberi jogot és intézményt, azonban ezen emberi jogok tartalmi jelentősége annál nagyobb. ${ }^{3}$

E tanulmányunkban csupán az ember élethez és méltósághoz való jogával kívánunk foglalkozni, rámutatván arra, hogy ezek csak akkor védhetők hatékonyan, ha az ember természeti, teoretikusan megragadható lényegét a szellemi lelkében azonosítjuk - ami minden emberi lény feltétlen és abszolút méltóságát adja -, s ami a fogantatásától a haláláig jelen van, mindvégig tehát, amíg az emberi személy a teljesen egyedi testében él és létezik. Ú Úg gondoljuk, hogy ezt a gondolkodást, valóságlátást a legkövetkezetesebben a keresztény szemléleti alapállás érvényesíti. A keresztényi hozzáállás más lehetett abban az időben, amikor a fenti libertárius, ideológiai alapokon nyugvó „jogkövetelések” még nem léteztek, hanem a Nyilatkozat a valódi emberi természeten nyugvó emberi jogokat kívánta kinyilvánítani, hiszen azok létét - nagy általánosságban - mindenki osztotta. Manapság viszont, a mainstreamnek tekinthető libertárius retorikában egyrészt tagadják a Nyilatkozatban foglalt egyes legfóbb emberi jogok igazi, valódi értelmét és tartalmát, másrészt az emberi természettel ellentétes „jogoknak” nevezett követelések kerekedtek fölül az emberi jogi érvelésekben és a törvényhozási és a bíráskodási gyakorlatokban is.

A helyes (katolikus) érvelési kiindulópont tehát csak az lehet, hogy az emberi személy lényegi természetéből indulunk ki, ami a méltóságának és a legalapvetőbb emberi jogainak érvényességi tartalmi alapját adja, s ami - mint írtuk - a minden emberben benne levő szellemi lélek, ami metafizikai, s így transzcendens, ezért tehát alapvetően csak vallási módon értelmezhető, szent valóság. Ez adja tehát az emberi méltóság alapját, indokát és létokát, ami ugyanezért szintén metafizikai és transzcendens, s ily módon vallási töltetű valóság, vagy ahogy Robert Spaemann fogalmaz: a szentség egy jele. ${ }^{5}$ Ma már nem járhatjuk azt az utat, amit Jacques Maritain még felvállalhatott a Nyilatkozat megszövegezésekor, azt tehát, hogy zárójelbe tesszük az emberi jogok teoretikus filozófiai megalapozását, azok alapjának kijelentését, pusztán csak azért, mert abban nincsen széles körű egyetértés.

Mára már bebizonyosodott, hogy nem lehetséges pusztán csak kijelenteni az emberi jogokat, hiszen azoknak az emberi természettől való elvonatkoztatása a fent említett következményekre vezetett. Úgy véljük, hogy annak kinyilvánítása, hogy az ember szellemi lélekkel rendelkezik fogantatásától kezdve, bár a legteljesebben a keresztény,

ber szívébe van írva, s ott az múködik. Az már más kérdés, hogy egy szekuláris liberális eszmerendszerben - amelyet többen vallottak - koherens racionális teoretikus érvelésben nem voltak igazolhatók e jogok. Elinor Gardner: Nature and Rights: The Meaning of a Universal Agreement on Human Rights. In Giuseppe Butera (szerk.): Reading the Cosmos: Nature, Science, and Wisdom. Washington, American Maritain Association, 2012. 215-228. 221-222.

3 Vö. Frivaldszky János: Természetjog és emberi jogok. Budapest, Pázmány Press, 2010.

4 Az emberben a test és a szellem viszonyához ld. pl. James Capehart: Incarnate Spirit: Proper Thomistic Definition of the Human Being or Merely Description of the Human Soul? In John J. Conley (szerk.): Redeeming Philosophy: From Metaphysics to Aesthetics. Washington, American Maritain Association, 2014. 83-98.

5 Robert Spaemann: Tre lezioni sulla dignità della vita umana. Torino, Lindau, 2018. 45. 
sőt a katolikus álláspontban érvényesül, és így védhető a leginkább, mégis arra el lehet jutni intuíció és tapasztalat révén is, s ekképpen Istenben nem hívő gondolkodók és az átlagember is vallhatja azt. Sőt amellett, hogy a lélek az emberi személy leglényegibb alkotóeleme, még a kortárs agykutatásokkal való párbeszédben is hatásosan lehet érvelni. ${ }^{6} \mathrm{~A}$ feladat így csak az lehet, hogy ezt az igazságot minél alaposabban és többféle módon bizonyítsuk tudománypozitivista beállítottságú korunkban is, aminek azért mindazonáltal kedvező körülményt ad az a tény, hogy újabban a valamilyenfajta spirituális dimenzió felé való fordulás szélesebb rétegekben tapasztalható belső érzelmi és értelmi igényként mutatkozik.

A Nyilatkozat megfogalmazásának korában számos világnézeti irányzat egy irányba mutatóan kiáltott az emberi jogok kinyilvánításáért és érvényesüléséért, $\mathrm{s}$ bár csírájában már jelen volt a transzhumanizmus szekuláris vallása is, ${ }^{7}$ talán a legmarkánsabbnak a haladó liberális humanizmus volt tekinthető, miközben a keresztény perszonalizmus jelenléte is érezhető volt, többek között természetesen Maritain hatására. A II. Vatikáni Zsinat után a katolikus gondolkodóknál a természetjogi gondolatiság jobbára voltaképpen egyet jelentett a helyes értelemben vett emberi jogok tanával, amelyek kibontására számos egyházi dokumentum született. A katolikus szemléletű emberi jogok tana olyannyira kibontakozott, hogy az 1990-es érvekre már az vált kérdésessé, hogy szüksége van-e még a katolikus Egyháznak a természetjogi gondolkodás teoretikus eszköztárára mint az emberi jogok megalapozására, vagy az emberi jogok doktrínája olyannyira szilárdan megáll magában, hogy az mintegy implicit módon felszippantotta azt. ${ }^{8}$

Az emberi jogokban a méltóság fémjelezte emberi jelleg többek között - az embertömegeket érintően - az emberi(es)ség ellenes bűncselekmények kinyilvánításával

6 Ld. pl. Juan J. Sanguineti: Soul and Person Commentary on «Your Soul is a Distributed Property of the Brains of Yourself and Others» by Michael A. Arbib. Italian Journal of Cognitive Sciences, 3. (2016), 2. 243-252.

7 Létrejöttekor a transzhumanizmus evolucionista alapokon nyugvó, kinyilatkoztatás nélküli, azaz evilági, szekuláris vallás volt, Julian Huxley megfogalmazása szerint egy új hit. Julian S. Huxley: Religion without Revelation. New York - London, Harper and Brothers, 1927;

Julian S. Huxley: New Bottles for New Wine. London, Chatto and Windus, 1959. 17. Amikor Jacques Maritain az UNESCO által erre felkért bizottság elnökeként a Nyilatkozat preambulumának megszövegezésén dolgozott, akkor az emberi jogok védelmére, s nem azok teoretikus megalapozására helyezte tudatosan a hangsúlyt, minthogy olyan nagy volt a világnézetekben való különbözőség a jogok alapjait illetően, hogy nemhogy konszenzusra, hanem még egy irányban történő gondolkodásra sem igen volt reális lehetőség. Rá kell mutatni arra is, hogy közgyűlésének Mexikóvárosban tartott második ülésszaka alatt Huxley volt történetesen az UNESCO első általános igazgatója, míg Maritain vezette a francia delegációt. Az UNESCO vezetésének e légkörében Maritain vélhetően nem tudta az emberi jogok érvényességi alapjául álló, a természeti törvény történelmi fejlődés keretében való megismerésének saját - Szent Tamás-i - elméletét érvényesíteni, hanem inkább az egység keresésére helyezte a hangsúlyt 1948 februárjában és később is. A Nyilatkozatot végül az ENSZ Közgyűlése 1948. december 10-én fogadta el. A szövegezőbizottságot és a dokumentumokat ld. http://research.un.org/en/undhr/draftingcommittee (A letöltés dátuma: 2020. 10. 02.)

8 Francesco D’Agostino: A természetjog kérdése az egyház társadalmi tanításában. In Frivaldszky János: Természetjog. Szöveggyüjtemény. Budapest, Szent István Társulat, 2006. 257-271. Különösen ld. 261-262. 
vált pregnánssá. Továbbá a humánumot idővel már a gyermeki létben alapvető, emberi jogi szinten is érzékelték, és így tudatosították annak ártatlansága és szépsége, kedvessége, bájossága, és „sűrítetten”, tisztán jelen levő igazi, de ugyanakkor rendkívül sérülékeny humanitása révén, ami a gyermeki jogok deklarációjának megfogalmazását is ihlethette. Azonban a kortárs libertárius és utilitarista bioetikai, morál- és jogfilozófiai elméletek nyomán sajnos megakadt a gyermeki jogok alapvető emberi jogokként történő komolyan vétele. ${ }^{9}$ A gyermekeutanázia botrányos jelensége önmagában mutatja azt, hogy korunk embere, a felnőtt a saját helytelen értékrendje felől ítéli meg a gyermek életének értelmességét, azaz annak vélt „értelmetlenségét” is. Vigasztaló fejlemény azonban, hogy az összetört, csúnyának ható testben élő emberi személy esetében is a halál megélését az emberben levő szellemi lélek a halál előtt különös módon megnyilvánuló transzcendens volta és az ember arra való irányultsága miatt egyre többen valamiféle, az emberi személyi méltóságot és az (e világon már megkezdődő örök) élet értelmességét kiteljesítő szent dolognak tartják. ${ }^{10}$

Ennek következtében az eutanáziát és az asszisztált öngyilkosságot pártolóknak komoly eufemisztikus nyelvújítási eredményekre („kegyes halál”, „jó halál”) és a nyelvpolitikai eszköztár (az asszisztált öngyilkosságot az USA bizonyos államiban törvényileg nem lehet tulajdonképpeni nevén nevezni) ${ }^{11}$ bevetésére van ahhoz szüksége, hogy azt a széles közönség előtt humánusnak állítsák be. Ezzel szemben az emberi embrióban, mivel az kinézetre még nem emberszerü és még nem bájos, sokan még nem érzékelik ezt a lelki (spirituális) dimenziót, s így empátiát sem képes mindenkiben minden további nélkül kelteni. Itt van különös szükség a teoretikus bizonyításra, illetve a gondolati következetességre, hogy a lelket ne a racionális-morális (külső) tevékenységhez, illetve annak jövőbeli képességgyakorlásához kössük. Ez annál inkább is nehéz, mivel a perszonalizmus, így a keresztény is, az emberi személy személyközi relációiban tökéletesedö - ideértve elsőrendűen a transzcendenssel, vagyis az Istennel való kapcsolatát is - és kiteljesedő lelki-morális megvalósulására helyezi a hangsúlyt, amelyben a természetes erkölcsi törvény arra sarkallja és kötelezi őt, hogy váljon $a z z a ́$, ami lényege szerint. ${ }^{12}$

Egy ilyen optikában a morális személyiségfejlődés és az ember társas, szociális kibontakozása a nyomatékos, amelyet az emberi személy önkifejlesztéséhez való joga

9 Frivaldszky János: A jogfilozófia alapvetö kérdései és elemei. Budapest, Szent István Társulat, 2019. 102-109.

10 Marie de Hennezel - Jean-Yves Leloup: A halál müvészete. Hogyan nézzünk szembe a halállal? Vallási hagyományok és humanista spiritualitás napjainkban. Budapest, Európa, 1999. Különösen ld. 90-92., 112., 116., 120-121., 126., 132., 152., 163., 166.

11 Hegedűs Katalin: Létezik-e jó halál? Budapest, Oriold és Társai, 2017. 94.

12 A személy fogalmának és a filozófiai perszonalizmus rövid, de lényeglátó történetéhez ld. Giovanni Lauriola: La persona: storia di un concetto. In Giovanni Lauriola (szerk.): Diritti umani e libertà in Duns Scoto. Alberobello (Bari), A.G.A., 2000. 125-150. Meg kell jegyezni, hogy a filozófiai perszonalizmus képviselői is jobbára kritikusan tekintettek a természetjogi elmélet kortárs vonulatára. Giuseppe Mazzocato: L'indirizzo personalista ed i suoi problemi. In Giuseppe Angelini (szerk.): La legge naturale. I principi dell'umano e la molteplicità delle culture. Milánó, Glossa, 2007. 151. 
sürít magába. ${ }^{13}$ Ezzel szemben a lélek nyilvánvalóan nem az erkölcsi és racionális cselekvéseiben való majdani potenciális kibontakozása miatt képez feltétlen értéket a haldoklóban, de az emberi embrióban sem, aki lehet, hogy meg sem éri a megszületését vagy a születése utáni első hónapjait. Az emberi lélek önmagában, bármiféle külsőleg érzékelhető tett, cselekedet vagy képesség nélkül adja az ember feltétlen méltóságának alapját a fogantatásától kezdve egészen a haláláig. Ez a keresztény, s így a katolikus tanítás. A perszonalizmus - imént említett - gondolati alapállása alig alkalmazható tehát az emberi embrió azon életállapotában is jelen levő lényegének, a szellemi lelkéből fakadó feltétlen emberi személyi értékének fogalmi megragadására.

A jogász alapvetően nagyon jó intuíciókkal rendelkezik, így például a volt emberi személy tiszteletének megsejtésénél (kegyeleti jogok), néha azonban nem látszik tovább látni az orránál, s nem veszi észre, hogy adott esetben nem egy dologról, hanem emberi lényről van szó (a méhmagzat esetében), máskor pedig formakonzervativizmusában a merev logikai konstrukcióinak a foglya, például a német pandektista jogképesség fogalmában való gondolkodáskor, még akkor is, ha az nyilvánvalóan elfedi az ember jogalanyiságát és személy voltát a méhmagzati stádiumában. Ezt egy egészségesebb, a méhmagzati ember életére - a 4D-s ultrahangok és a legújabb genetikai kutatások korában - realistábban tekintő alkotmányjogi gondolkodásmód már rég felülírná vagy felülírhatná. Ez utóbbi logikájában a mindenkit „születésétől fogva” megillető élethez és a jogalanyisághoz való jog nem jelenthet mást, mint hogy mindenki természeténél fogva emberi személy és jogalany, amikortól egyedi emberi lényként él és létezik, azaz a fogantatásától fogva. Attól még, hogy esetleg érzelmileg, iránta empátiát ébresztően nem ragad magával egy ebihal- vagy szalamandraalakra hasonlító méhmagzati emberi lény, ${ }^{14}$ teoretikusan tudatosítandó, hogy az ugyanolyan emberi személy, mint mindenki más, azaz „egy közülünk”, tehát az emberiség tagja feltétlen méltóságú emberi lényként.

A helyes jogi állásponthoz tehát néha nem elégséges az egyszerủ intuíció vagy a primer tapasztalat, $\mathrm{s}$ különösen helytelen a jogképesség kategóriájának merev használata az emberi embrió alanyiságának fogalmai megragadására, mert az magát a valóságot hamisítja meg nagyon súlyos következményeket hordozóan. Ahhoz, hogy a dominánssá váló helytelen - sokszor ideológiai alapú vagy érdekvezérelt - gondolkodásmódokkal szemben a valóságot állíthassuk, a jogásznak azon érzékére kell hagyatkoznia, ${ }^{15}$ amely az emberben, minden emberben a legemberibb, a legsajátlagosabb dimenziót azonosítja, a szellemi lelket, amely az embert feltétlen értékűvé és méltóságúvá teszi.

13 Vö. pl. Domenico Coccopalmerio: Fortitudo Iuris. Persona e diritto. Trieszt, LINT, 1989.

14 Michael Slote: The Ethics of Care and Empathy. Abingdon, Routledge, 2008. 18.

15 A jog gyakorlásának gyakorlati művészete (ars), ahogy azt a római jogászok értették, a jogképesség formális és absztrakt kategóriáján túl képes észlelni a méhmagzatban az emberi személyt és annak jogalanyiságát. Vö. Pierangelo Catalano: Linizio della „persona umana” secondo il diritto umano. In Andrea Trisciuoglio (szerk.): Valori e principii del diritto romano. Nápoly, Scientifiche Italiane, 2009. 33-34., 36. 


\section{Egyetértés az emberi jogok konkrét tartalmát, de nem azok alapját illetően}

A Nyilatkozat szövegezésének korszakában általános gyakorlati egyetértés mutatkozott az emberi jogok azon konkrét normatív tartalmait illetően, amelyeket megfogalmaztak. Azonban konszenzus hiányában hiányzott egy olyan teoretikusan-racionálisan megfogalmazott filozófiai antropológia, amely az érvényességi alapjukat tekintve megalapozta volna ezen emberi jogokat. Vagyis hiányzott az emberi természet forrását, célját és így vett mibenlétét illető egyetértés. Mindenki egyetértett a deklarált emberi jogokban, de nem azok érvényességének miértjében, mert ha arra rákérdeztek volna, akkor az vitát eredményezett volna. ${ }^{16} \mathrm{~A}$ megfogalmazott emberi jogok így csak annyiban tekinthetők „természetes” jogoknak, hogy nem egy esetben szerepel a szóhasználatban a „veleszületett” kitétel a nevezett jogok előtt. Ez azonban „csak” annyit jelent, hogy nem a pozitív jog azok érvényességének a forrása.

A Nyilatkozat azonban nem fogalmazza meg azon, az emberi természetben rejlő forrás mibenlétét, így például az emberi méltóságnak a forrását, amely meghatározott emberi természeten alapulván természetjogi módon tartalmazná és írná elő ezen emberi jogokat és intézményeket. E hiány okából fakadóan a deklarált emberi jogok valamiképpen elveszítik meghatározott, tartalmi értelemben vett természetjogi alapjukat, mivel ez utóbbi feltételezné az egyetemes emberi természet általános elismerését. ${ }^{17}$ Ily módon a Nyilatkozat megfogalmazásában közreműködő felek csupán a maguk számára igazolták - a saját maguk számára érvényes, de a többiekétől különböző teoretikus igazolási módon - az emberi jogok érvényességi alapját, amiben tehát nem volt egyetértés, s csak a cselekvést, azaz az emberi jogokat védő gyakorlati konklúziókat tekintve mutatkozott effektív konszenzus. ${ }^{18}$ Az akkori pragmatikus hozzáállás szerint praktikusan nem volt annak végül is különösebb jelentősége, hogy a Nyilatkozat elfogadói miben fogalmazzák meg a maguk számára az említett jogok végső érvényességi alapját, a fontos - politikai - praktikus szempontból az volt, hogy azok hatékony nemzetközi védelme megvalósuljon, amihez e deklaráció a maga közvetett és szimbolikus eszközeivel kívánt hozzájárulni.

Ez rendjén is való volt egy olyan nemes célt tekintő politikai pragmatizmus szintjén, amely alapján konszenzussal meg lehetett egyezni a védendő jogokban a tömeges jogtiprások időszaka után. ${ }^{19}$ A Nyilatkozat mögött rejlő konszenzus kompromisszuma az volt tehát, hogy az emberi természetre és annak forrására való utalás zárójelbe került, ami által végeredményben az emberi jogok természetjogi alapjának kimondása

16 Vö. Jacques Maritain: Man and the State. Washington, Catholic University of America Press, 1998. 77.; Norberto Bobbio: Sul fondamento dei diritti dell'uomo. Rivista Internazionale di Filosofia del Diritto, 42. (1965), 302-309.

17 Reginaldo Pizzorni: Diritto naturale e diritto positivo in S. Tommaso d'Aquino. Bologna, Studio Domenicano, 1999. 221.

18 Vö. Maritain i. m. (16. lj.) 78.

19 Leonardo Messinese: La concezione della legge naturale in Jacques Maritain. In Renzo Gerardi (szerk.): La legge morale naturale, problemi e prospettive. Róma, Pontificia Università Lateranense, 2007. 424 . 
is elmaradt. Ezáltal azonban - tézisünk szerint - az emberi jogok nem kaptak sem természetjogi védelmet, sem természetjogi tartalommeghatározást, ami az emberi jogok majdani érvényesülésére, annak mikéntjére is rányomta a bélyegét. Az emberi jogok tudatosan vállalt abszolút érvényü filozófiai megalapozásnélküliségének ténylegessége ${ }^{20}$ a teoretikusan vállalt filozófiaialap-nélküliségükbe váltott át (azt hangoztatták, hogy „az emberi jogok filozófiailag nem alapozhatók meg”), majd idővel a normativ módon tételezett értékrelativizmus, illetve olykor a nihilizmus filozófiai közegében a libertárius politikai ideológiák „emberi jog”-érvényesítése révén végzett effektív nyomásgyakorlásába csapott át.

Maritain gondolatainak nyomdokán haladva mindazonáltal - egy helyesen értelmezett pozitív megközelítésben - úgy is fogalmazhatunk, hogy a közösen osztott, megtapasztalt igazságmagvakból kiindulva volt lehetséges egyfajta pragmatikus politikai konszenzus, mert a természeti törvény „hajlam szerinti megismerése" ${ }^{21}$ müködött az emberiség erkölcsi tudatában, ami viszont pretudományos és prefilozófiai elsődleges megismerési mód, és így az még nem kíván, s nem feltételez rögtön teoretikus megalapozást és reflektív tudományos-filozófiai tudást is. ${ }^{22}$

\section{Maritain: „praktikus igazság” és az emberi jogok természetjogi alapja - egy kompromisszum problémája}

Az említett deklaráció preambulumának megfogalmazása előkészületeiben részt vevő Maritain keresztény természetjogi alapokon közelítette meg az emberi jogokat, azok eredetét, érvényességét és tartalmát. ${ }^{23}$ Amikor azok megismerhetőségének tárgyalásába és tartalmainak kifejtésébe fogott a természeti törvénytan bázisán, akkor Aquinói Szent Tamás nyomdokain haladva keresztény filozófiai alapokon érvelt. ${ }^{24}$ Egyrészt az emberi jogok tartalmi érvényességét illetően azok Istentől való eredetét hangsúlyozta, mivel az emberi személy méltósága az ember Isten képmására való teremtettségéből származik, másrészt viszont azt állította, hogy a természeti törvény

20 Norberto Bobbio: L'età dei diritti. Torino, Einaudi, 1997. 16.

21 A fogalomhoz ld. Marco D’Avenia: La conoscenza per connaturalità in S. Tommaso D’Aquino. Bologna, Studio Domenicano, 1992.

22 Messinese i. m. (19. lj.) 426.

23 Az emberi jogok tárgyalásakor az emberi személy keresztény értelemben vett transzcendens méltóságából indul ki, s hozzáteszi, hogy ez a transzcendencia a „legnyilvánvalóbban a hit és a megváltás perspektívájában létezik”, majd úgy folytatja, hogy „de azóta e méltóság tudata fokról fokra teret nyert a természetes rendben is, behatolva a természet törvényéről és a természetjogról való tudásunkba, s megújítva azt". Jacques Maritain: A személy jogai, a politikai humanizmus. In Frivaldszky János (szerk.): Természetjog, szöveggyüjtemény. Budapest, Szent István Társulat, 2006. 90-92. Az alapvető gondolatok azonban már 1942-ben megvoltak, mivel ezen év májusában, New Yorkban publikálta Les droits de l'homme et loi naturelle című munkáját.

24 Azon kérdéshez, hogy létezik-e keresztény természetjogi gondolkodás, vagy hogy csak e teológiai alapú érvelés használható-e egy keresztény filozófus, jogfilozófus számára, ld. Giovanni Ambrosetti: Diritto naturale cristiano, profili di metodo, di storia e di teoria. Róma, Studium, 1970. Manapság újból hangsúlyozzák, hogy az emberi jogokat kifejezetten az isteni jogalapú természeti törvényre szükséges alapozni. 
legáltalánosabb elő́rásait minden ember a „természetes hajlam” alapján, azaz a természeti törvény emberben való működése alapján, természetes módon megismerni képes.

Szent Tamás szerint ugyanis a természeti törvény az örök törvény részvétele az emberi észben. Az ember tehát megismerni képes e törvényt pusztán természetes hajlamainak céljaira reflektáló természetes racionalitása által. Maritain, aki egyébként, mint látható, keresztény alapokon, természetjogi módon alapozta meg írásaiban az emberi jogokat, úgy tudta ezen alapokat feltárni és azok megismerhetőségét bemutatni, hogy ontológiailag és ismeretelméletileg - a végső forrás (örök törvény) elfogadása nélkül is - megalapozottként fogadhatta el e jogokat bárki. Ebben azon koncepciónak volt kiemelkedő szerepe, miszerint a természeti törvényt „természetes hajlam" alapján ismerjük meg elsődlegesen, s amely tan eredetileg Szent Tamástól származik. ${ }^{25}$ Vagyis a Nyilatkozatnak pusztán a gyakorlati konklúziókat érintő politikai konszenzusa mögé az emberi jogok megismerésének tudományos igazolását úgy tudta nyújtani Maritain egy mérvadó közönség számára, hogy azt ezen episztemológiai, azaz a természetes hajlamon nyugvó megismerésorientált szemléletmódja, annak érvényesülése miatt voltak képesek elfogadni. Eközben Maritain a természeti törvény ezen episztemológiája mögött rejlő ontológiai tudományos-filozófiai érvényességi magyarázatát tomista módon adta meg, s így az emberi személy méltóságát és abból fakadó jogait keresztényi értelemben vett természeti törvényi alapokon állóknak tekintette.

Az emberi jogok forrásául szolgáló emberi méltóság isteni jogú megalapozása és a morálteológiai teoretikus érvelés nem jöhetett szóba a Nyilatkozat megfogalmazásakor, mivel e teoretikus-teológiai alap elfogadása a (keresztény) vallásos hit világába tartozik, miközben a Nyilatkozat szövegének megfogalmazói többféle valláshoz és ideológiai meggyőződéshez tartoztak. ${ }^{26} \mathrm{~A}$ természetjog hitbéli igazság-szférájába tartozó érvényességi alapjának feltárására, azaz az örök törvény tartalmának kifejtésére és az abban való egyezségre - ezen igazolási módok dogmatikusaknak tekintetvén kölcsönösen elutasíttattak volna, ezáltal végeláthatatlan vitákat szülve -, s így a természeti törvény törvényalkotói forrásának meghatározására eleve nem volt lehetőség. Lehetővé vált ugyanakkor a természeti törvény episztemológiai, azaz az individuális és a kollektív civilizatorikus síkon érvényesülő, egyre kiteljesedően megismert tartalmaknak a hangsúlyozása, vagyis a megismerő alanynak (ember, emberiség) a megismerésben betöltött szerepének, valamint a megismerés módjának (hajlam szerint, természetazonosság révén) a kiemelése, a kapott, azaz a kötelezőként megismert emberi jogi tartalmakkal együtt. Lehetőség volt tehát az emberi jogok konklúziószerü tartalmának episztemológiailag biztos meghatározására, s ennek következtében azok konszenzusos politikai kinyilvánítására. ${ }^{27}$

25 D’Avenia i. m. (21. li.).

26 Ld. Dag Hammarskjöld Library: Drafting Committee - Members. Elérhető: https://research. un.org/en/undhr/draftingcommittee (A letöltés dátuma: 2020.10.02.)

27 Vö. Maritain i. m. (16. lj.) 76-80. 
Azt is el kell azonban mondanunk, hogy pontosan meghatározott érvényességi forrás és teoretikusan megfogalmazott, közösen osztott ontológiai rend adta keret és alap nélkül ezen jogok - akaratlanul is - olyan bizonyítatlan axiómák lettek, amelyek metafizikailag rögzített természetjogi alap híján, voltaképpen érvényességi forrás híján, s így értett kötelező erő hiányában a) végül is védtelenek maradtak; b) jogi tartalmukat, ${ }^{28}$ értelmezésüket tekintve pedig irányvesztetté váltak, c) továbbá a mögöttes emberi természet nélkül az egyes jogok egymástól elszakíthatók, ${ }^{29}$ sőt egymással szembeállíthatók, illetve egymással szemben kijátszhatók lettek.

Az emberi jogoknak a pozitív jogi forrástól, azaz a politikai hatalomtól való független kötelező erejét volt hivatva kifejezni az, hogy a Nyilatkozatban bizonyos emberi jogok elött a „veleszületett” jelző szerepel. Mivel azonban a Nyilatkozat pozitív jogi kötelező erővel nem rendelkezik, s a forrásul szolgáló emberi természet lényegi mibenléte meghatározásának elhagyásával tulajdonképpen a természetjogi megalapozás is zárójelbe került (s csupán a „veleszületett” jelzőre redukálódott), így kétségessé vált az emberi jogok tágabb, jogfilozófiai értelemben vett kötelező tartalmának mibenléte is. Időközben számos emberi jogi dokumentumot fogadtak el, amelyek pozitív jogi kötelező erővel rendelkeznek, így többek között a Polgári és Politikai Jogok Nemzetközi Egyezségokmánya is, azonban az emberi jogok érvényességi alapjának hiányából fakadó problémák nem oldódtak meg, sőt mintha fokozódni látszanának.

Mivel az említett dokumentumok több-kevesebb politikai elemet is magukban rejtenek, minthogy a jogok nemzetközi vindikációját tartalmazzák, így a jogok politikai igénybejelentésének kultúráját is elterjesztették. Ez a posztmodern korban egyfajta libertárius szemléletben tekintett „igényjogok” követelésének egész politikai kultúráját teremtette meg, amely jogigények sok tekintetben nyilvánvaló ellentétben vannak a Nyilatkozatban foglalt emberi jogokkal, illetve az emberi természeten alapuló intézményekkel (házasság, család). ${ }^{30}$ Ennek hatására neves kortárs katolikus - a klasszikus hagyományokat folytatva a metafizikai valóságból kiinduló - jogfilozófusok fordultak az emberi jogok kortárs kultúrája ellen, látva azt, hogy az egyre inkább a libertárius

28 A Nyilatkozat pozitív jogi értelemben vett kötelező erővel nem rendelkezik, azonban az emberi jogi gondolkodás alakulását nagymértékben befolyásolta.

29 Bizonyos jogokat egyes emberi jogi törekvések abszolutizálva kiragadnak emberi jogi összefüggésükből, márpedig ez ellentétes a Nyilatkozat szellemével. Vittorio Possenti: Il principio-persona. Róma, Armando, 2006. 108. A jogok világa koncepcióhoz, vagyis az emberi jogok összefüggő rendszert alkotó jellegének természetjogi (gyakorlati filozófiai) tárgyalásához ld. Francesco Viola: I diritti umani: una nuova forma di diritto naturale? In Giuseppe Angelini (szerk.): La legge naturale. I principi dell'umano e la molteplicità delle culture. Milánó, Glossa, 2007. 137-149. Nézetünk szerint vannak olyan alapvető emberi jogok, amelyek helyes (!) értelmükben abszolútak, így például a jogalanyisághoz, az élethez és az emberi méltósághoz való jog olyan alapvető jogok, amelyek az emberi természetből abszolút módon, korlátozhatatlanul fakadnak. Azonban e jogok is az emberi személy lényegéhez kötötten nyernek értelmet és tartalmat, mivel ezek „emberiek” és a „személyhez" tartoznak.

30 Az elmúlt évtizedekben a genderfeministák a nemi szerepekben való gondolkodás teljes forradalmasításáért, illetve azok megszüntetéséért folytattak kampányt, így többek között az ENSZ által szervezett 1995-ös pekingi női világkonferencián is. Oscar Alzamora Revoredo: A genderideológia: veszélyek és lehetőségek. Embertárs, (2008), 1. 11-23. 
politikai voluntarizmus relativizmusától, illetve nihilizmusától vezérelt, minthogy az racionális érvekkel filozófiailag és jogilag igazolhatatlan. ${ }^{31} \mathrm{E}$ vonulatba illeszkedik Michel Villey alapállása is, aki az alanyi, illetve az emberi jogok egész modern tradícióját utasította el jogfilozófiai megfontolásokból. ${ }^{32}$

Úgy véljük azonban, hogy ehelyett a valódi emberi alapjogok tanát szükséges megerősíteni az ember természetjogi igazságainak védelmében, miközben el kell utasítani az emberi jogokkal való teoretikus és politikai-ideológiai visszaéléseket, mert azok az emberi természet, s ezért az ember kiteljesedése ellen valók. Természetjogi nézőpontból ugyanis nagy különbség van azon helyzet között, amikor egyetemesen osztott, természetjogilag megalapozott természetes jogok kinyilvánítása (felismerő elismerése) és érvényesítése történik, $\mathrm{s}$ a között a napjainkban elterjedt - s az imént hivatkozott - helyzet között, amikor természetjogi igazolás nélküli vagy egyenesen a természeti törvény előírásaival szemben álló igényeket politikai eszközökkel igyekeznek elfogadtatni és pozitív joggá tenni, azaz kikényszeríteni politikai vagy ideológiainak tekinthető megfontolásokból. Ezen utóbbi természetjog-ellenes, „emberi joginak" nevezett igények és követelések, még ha pozitív jogi formát öltenének is, természetjogi értelemben vett jogi érvényességgel és kötelező erővel nem rendelkeznek. Mindezen kortárs problémák tehát abból fakadnak, hogy a Nyilatkozatban deklarált jogok nem rendelkeznek kifejezett módon közösen kinyilvánított természetjogi alappal.

A jogok eredetét tehát Maritain a természeti törvényen keresztül az örök törvényre vezeti vissza, miközben a természeti törvény megismerését oly módon fejti ki, hogy azzal sokféle vallási, illetve ideológiai meggyőződésű ember egyetérthet, ha a Nyilatkozatban foglalt emberi jogokat osztja, s amennyiben az azokba vetett szekuláris „hit” vezeti. Maritain bemutatásában az ember ugyanis hangsúlyosan történeti lény, „kulturális lény”, ${ }^{33}$ így a természeti törvény kifejtése kultúrfilozófiai elmé-

31 Danilo Castellano: Razionalismo e diritti umani. Dell'antifilosofia politico-giuridica dell „modernità". Torino, Giappichelli, 2003. Ld. különösen 91.

32 Michel Villey: Il diritto e i diritti dell'uomo. Siena, Cantagalli, 2009. Danilo Castellano egyébként nem ért egyet a francia jogfilozófussal abban, hogy ne lehetne az (individuális) emberi természetből jogokat levezetni. Castellano i. m. (31. lj.) 2-3. és 5. jegyzet. Sok kritika érte Michel Villey-t a tekintetben - elég csak Giovanni Ambrosettire utalni -, hogy a modern észjogi absztrakt természetjog individualista emberképének bírálatában túlságosan is a másik oldalra billent át, így túlzottan is pragmatikusan, ekképpen pedig elméletellenesen, antifilozofikusan közelíti meg a természetjogot és az annak alapjául álló természetet mint a politikai csoportok természetét. Ambrosetti i. m. (24. lj.) 38-39. Az empirikusan, szinte már szociológiailag leírt csoportok természetéből ugyanis éppen a normatív jelleg tünik el. Kétséges az is, írja Ambrosetti, hogy a rómaiak természetjoga sem lett volna más, mint az „igazságos” nyitott, folyamatos gyakorlati keresése. Villey amikor - egyébként helyesen - jogfelfogásában nagy hangsúlyt fektet a személyközti kölcsönös igazságosságra, egyszersmind alul-, illetve helytelenül értékeli az alanyi jogosultságoknak és az emberi jogoknak szerepét a jog világában.

33 Jacques Maritain: Nove lezioni sulla legge naturale. Milánó, Jaca, 1985. 124. Vö. Francesco Viola Bevezetőjével, uo. 30-31., 34. Ez a kilenc előadás 1950-ben hangzott el. Előbb jelent meg olaszul, mint az eredeti nyelven. Ld. Viola uo. 12. A tényt, hogy az eredeti nyelv (francia) előtt olasz nyelven jelent meg Maritain e fontos műve, mindig megemlíti az olasz szakirodalom. L. Messinese i. m. 
leti keretben történik, amelyben az emberiség az említett törvény megismerésének a kitüntetett alanya. A természeti törvénynek az emberiség tapasztalatában és lelkiismeretében végbemenő történelmi megismerésének, azaz a természeti törvény történelmi civilizatorikus-kulturális értelemben vett gnoszeológiai elemének rendkívül hangsúlyos szerep jut tehát Maritain elméletében. ${ }^{34}$ Az emberiség így a történelmi tapasztalatok nyomán nyert lelkiismereti-tudati fejlődésének egy fontos pontján kötelezö erejüként ismer fel bizonyos emberi jogokat, és ezen felismerésben (recognition) a nyilatkozat(ok) megfogalmazói egyezségben vannak, szinte spontán módon abban voltak.

Maritain érdeme, hogy azáltal, hogy a természeti törvény - elsődleges, hajlam vagy természetszerintiség módján való - megismerésére, és nem pedig annak teoretikus módon megfogalmazható ontológiai oldalára irányította a figyelmet, hozzájárult az általános konszenzus eléréséhez az e törvényen alapuló emberi jogok vonatkozásában. ${ }^{35}$ Lehetséges volt tehát az egyetemes (általános) konszenzus a természeti törvény emberi jogokat előíró ismeretelméleti oldalának eredményeit illetően, miközben az azokat megalapozó ontológiai dimenzió - amelyet Maritain nemcsak vallott, hanem alapos és nagy hatású munkával ki is dolgozott - a háttérben maradt. ${ }^{36}$ Nyilvánvalónak tủnik, hogy Maritain természetitörvény-tanában kifejtett gnoszeológiai elem összhangban volt az emberiségnek a természeti törvény tartalmáról nyert átütő erejü történelmi tapasztalatával. Azonban ezen, a Nyilatkozat évében, 1948-ban érzékelhető optimista hangulat ${ }^{37}$ és - tehetjük hozzá - a mögöttes kultúrfilozófiai alap régóta eltünt immáron. Ily módon ez a természeti törvény és az emberi jogok kapcsolatának újrafogalmazását igényli - talán éppen Szent Tamás vonatkozó gondolataihoz való még szorosabb visszatérés révén.

(19. lj.) 409. Az olasz nyelvű kiadás nagymértékben alakította az olasz jogfilozófiai gondolkodást, különösen a természetjogászokét. Figyelemre méltó, hogy például egy nem régen megjelent brazil monográfia, amit a brazil Jacques Maritain-intézet adott ki, Maritain jogi gondolkodást megtermékenyítő életművét és annak jogi, alkotmányjogi kihatásait úgy tárgyalja, hogy egyáltalán nem alapoz az említett kilenc előadásra, márpedig - nézetünk szerint - enélkül sem Maritain természetjogi koncepciójának, sem emberi jogi gondolkodásmódjának megértése nem lehetséges. Lafayette Pozzoli: Maritain e o Direito. São Paulo, Loyola, 2001.

34 Maritain (1985) i. m. (33. lj.) 33.

35 Messinese i. m. (19. lj.) 424.

36 Uo. Fontos leszögezni, hogy Maritain abszolút fontosnak tekintette az emberi jogok teoretikus megalapozását. Mindazonáltal úgy tủnik, hogy azt inkább teológiai, keresztényi okokból tekintette fontosnak. Ld. Jacques Maritain: Il significato dei diritti umani. In Jacques Maritain: I diritti dell'uomo e la legge naturale. Milánó, Vita e pensiero, 1993. 121-149. Különösen 126., 132., 134-138., 140. Mi azonban ezen túl, jogfilozófiai szempontból is alapvetőnek tekintjük a teoretikus, fogalmi-deduktív megalapozást. Mondhatjuk, hogy ezt Maritain is lényegbevágónak tekintette (bár ő inkább morálfilozófiai igazolásról írt), azonban mégsem ezt az utat választotta, s ez figyelemre méltó. Akkor sem ezen igazolási módot tekintette az ő feladatának, amikor a Nyilatkozatot már elfogadták, $\mathrm{s}$ a konszenzus létrehozatalának pragmatikus kényszere már nem volt annyira égető. Azonban az is nyilvánvaló, hogy fogalmi-deduktív igazolás csak a legalapvetőbb jogok és intézmények esetében lehetséges és szükséges. 
A kérdés, amelyet a Nyilatkozat korunk számára felvet, az, hogy az érvényességi alapok igazolásától elvonatkoztatott emberi jogok tartalmainak gyakorlati igazolása mennyiben képes az emberi jogi kollíziókat feloldani szándékozó érvelést a helyes irányban tartani akkor, amikor közvetlenül az emberi természeti lényegen alapuló emberi jogokról van szó? A Nyilatkozatban megfogalmazott emberi jogok mint gyakorlati konklúziók, a természeti törvény Szent Tamás-i tartalmainak alapvetően megfelelnek. Nem így azonban azok ideológiai-politikai érdekeknek és szubjektív nézeteknek kitett további (félre)értelmezései. Ezek úgy keletkezhettek, hogy a deklarált jogokat, az emberi természeten nyugvó alapvető emberi intézményeket (házasság, család) a tartalmi kifejtésükkor elszakították az emberi természet tartalmi elemeitől (s tudjuk: eleve nem is kaptak ilyen tartalmi megalapozást már a deklarálásukkor), annak ontológiájától, ezáltal egyes jogokat kiemelve, a többi jogtól elszakítva, tehát nem az emberi természet lényegével, strukturált céljaival összhangban kezdték értelmezni azokat. Ennek eredményeképpen a deklarált emberi jogok nem egyszer önmagukban is deformált értelmet nyertek, ${ }^{38}$ vagyis az emberi jogi érvelés, igazolás keretében természetjog-ellenes, vagyis nem jogi tartalmakat vettek fel.

Így tehát megállapítható, hogy az emberi jogok tartalmainak alkalmazásukkor történő igazolása vagy az arra tett kísérlet még nem jelenti egyben egyszersmind azok érvényességének megalapozását is. Ez felveti az emberi természetről alkotott teoretikus tudás morál- és jogfilozófiai szempontú relevanciájának a kérdését. Az emberi jogok - Szent Tamás-i, természetjogi értelemben vett - fenti félreértelmezése láttán azonban mindenképpen már most felmerül a kérdés: lehet-e úgy igazolni az emberi jogok tartalmát, hogy közben nincsen azok végső érvényességi alapja feltárva, illetve ha nem ontológiai dimenziójukban és tartalmukban tekintjük azokat? Nézetünk szerint, a Tamás által kifejtett természetjogi tant alapul véve, nemcsak hogy nem lehet újabb emberi jogokat levezetni az emberi természeti lényeg, az emberi természet céljainak mellőzésével, hanem a Nyilatkozatban megfogalmazott emberi jogok helyes tartalmát sem lehet megállapítani a szó klasszikus - Szent Tamás-i vagy neoskolasztikus - ontológiai értelmében vett természetjogi érvelés és filozófiai megalapozás alkalmazása nélkül. Ebből következik, hogy az emberi jogok helyes értelmezése miatt az emberi természetet a jogfilozófia reflektív és normatív síkján jogi módon teoretikusan meg lehet és meg is kell fogalmazni. Még ha egy emberi jogi nyilatkozat mellőzi is ezt a filozófiai antropológiát, a jogfilozófia tudománya, specifikus hivatását szem előtt tartva, ezt már nem teheti meg.

Az emberi természet e teoretikusan megfogalmazott normatív lényegére vonatkozó tudásra mint az érvelés alapjára, azért van szükség, mert e nélkül nem lehet a legfontosabb emberi jogokat és természetes emberi intézményeket (házasság, család) levezetni, megalapozni, illetve nem lehet az ezzel ellentétes „emberi joginak” nevezett legújabb természetjog-ellenesnek tekinthető törekvéseket mint „nem jogiakat” érvénytelenekként elutasítani. Az ember számára való „emberi jónak” az emberi

38 Vö. Commissione Teologica Internazionale: Alla ricerca di un'etica universale: nuovo sguardo sulla legge naturale. Vatikán, Libreria Editrice Vaticana, 2009. 7-8. 
természet finalizmusában foglalt objektív és rendezett tudására van ahhoz szükség, hogy az annak eléréséhez, biztosításához való jogot mint kötelező jelleggel előírtat általános érvénnyel meg lehessen fogalmazni. A kérdés most már az, hogy mik ezen emberi javak, és hogyan fogalmazhatóak meg?

Korunkban az ontológiai, de egyáltalán mindenféle esszencialista érvelés elutasításra talál, tehát mindazon igazolási mód, amely egy emberi természetből indul ki mint a jogi érvényesség forrásából. Egyrészt az újkantiánus s egyben analitikus gyakorlati filozófiai gondolkodás „neoklasszikus” - egyébként Szent Tamást újrafogalmazva követő - természetjogi irányzata, ${ }^{39}$ másrészt a posztmodernitás egyes jegyeit hordozó pragmatista irányzatok utasítják el a jogi normáknak, emberi jogoknak egy elözetesen teoretikusan megfogalmazott egyetemes emberi természetből fakadó levezetését. ${ }^{40} \mathrm{Mi}$ azonban az alapvető emberi jogokat érintő jogi érvelésbe ezen, teoretikusan megfogalmazott emberi természet felvételét nélkülözhetetlennek tartjuk. ${ }^{41}$ A legalapvetőbb emberi jogok konkrét tartalmi meghatározása, azaz érvényességük megalapozása, lényegi normatív tartalmuk levezetése, illetve azok ily módon történő igazolása ugyanis nem mellőzheti az emberi természetről vallott - annak lényegi elemeit fogalmakban és normatív kijelentésekben, illetve azok logikai viszonyaiban megragadó - a priori teoretikus tudást. Ez utóbbit viszont a megismerést tekintve megelőzik az ember, minden - helyesen gondolkodó és cselekvő - ember, az emberi természetet intuitív módon feltáró-megértő alapvető erkölcsi megérzései, tapasztalatai. Más, az emberi lényegi természet alapvető normatív tartalmaitól távolabb eső emberi jogok érvényének és tartalmainak megalapozása - amelyek egyébként érvényükben és megfogalmazódási formájukban jobbára történelmikontextus-függők -, illetve azok kollízióinak feloldása viszont a klasszikus jogtudomány dialektikus prudenciális gyakorlati tudását is igényli, ami viszont egyre inkább a gyakorlati filozófia és érvelés világa. ${ }^{42}$

A fentiek azonban további kérdésekhez, tárgyalandó tematikákhoz vezetnek el minket. Így az is felvethető, hogy a gyakorlati filozófia megjelenési módjainak kü-

39 Tommaso Scandroglio: La teoria neoclassica sulla legge naturale di Germain Grisez e John Finnis. Torino, Giappichelli, 2012.

40 Vö. Frivaldszky János: Law as Practical Knowledge: Deconstruction, Pragmatism, and the Promise of Classical Practical Philosophy. In Alberto Martinengo (szerk.): Beyond Deconstruction: From Hermeneutics to Reconstruction. Berlin, De Gruyter, 2012. 255-275.

41 Frivaldszky János: Quale legge naturale per l'Europa dopo la scuola neoclassica del diritto naturale? In Marcello M. Fracanzani - Stefania Baroncelli (szerk.): Quale religione per l'Europa? Nápoly, Scientifiche Italiane, 2014. 51-72.; Frivaldszky János: Diritti umani e natura umana. In Giulio Maspero - M. Pérez de Laborda (szerk.): Fede e ragione: l'incontro e il cammino: In occasione del decimo anniversario dell'enciclica Fides et Ratio. Siena, Cantagalli, 2011. 149-158.; Frivaldszky János: Diritto naturale senza natura umana? In Antonio Malo (szerk): Natura, cultura, libertà: storia e complessità di un rapporto: comunicazioni del convegno della Facoltà di filosofia 2010, Pontificia Università della Santa Croce. Róma, EDUSC, 2010. 113-123.

42 Vö. Frivaldszky (2010) i. m. (3. lj.) 144-146.; Frivaldszky János: Legal Discourse: The Promise of Classical Practical Philosophy. In Maurizio Manzin - Federico Puppo - Serena Tomasi (szerk.): Studies on Argumentation and Legal Philosophy: Further Steps towards a Pluralistic Approach. Trento, Università degli Studi di Trento, 2015. 129-142. 
lönféle igazságigényei és igazolási módjai milyen természetủek, illetve milyen kapcsolatban állnak egymással. Vagyis az emberi jogok érvényesítése végett elvszerüen gyakorolt konszenzusorientált politikai pragmatizmus "gyakorlati igazsága”, vagyis az emberi jogokat érintő tartalmak „egymást átfedő konszenzusa”, illetve a jogalkalmazás kontroverziás-dialektikus prudenciális jogi érvelésének igazságigénye, továbbá a jogelméleti érvelés tudományos közösségének kortárs, jobbára analitikus igazolásorientált gyakorlati filozófiaként megfogalmazott - nézetünk szerint - morál- és politikai filozófiájának állításai milyen relációban állnak egymással? Egyáltalán, az az elsőrendủ kérdés, hogy van-e a politikai, illetve a jogi gondolkodás tudományos szinten létrejövő vagy csak áhított bármiféle konszenzusának relevanciája az emberi jogok érvényessége tekintetében, és ha igen, akkor milyen keretek között?

A rögtönzött válaszunk az, hogy az alapvető emberi jogok tekintetében csak az emberi természetből fakadó instanciák között lehet érvényesen érvelni e jogok tartalmának kérdéseiben. Mivel az emberi jogok Maritainnél természeti törvényi, illetve természetjogi alapokon állnak, ezért felmerül a kérdés, hogy mi az emberi természet és a természeti törvény megismerésének a szerepe és módja az emberi jogok megfogalmazásában. A természeti törvény megismerésének elsődleges, azaz egyéni, illetve az emberiség szintjén történő, valamint reflektív, azaz másodlagos, filozófiai tudományos megismerési módjait kell e tekintetben megkülönböztetnünk. Az emberiség szintjén történő megismerési szintet kifejezetten Maritain természetitörvénykoncepciója miatt szükséges elemezni. A továbbiakban látni fogjuk, hogy maga a kérdésfelvetés is némileg más Maritain korában, az emberi jogok megfogalmazásának optimista légkörében, és más problémáktól terhes korunkban, amikor sokszor csak üres, tartalom nélküli formulákká váltak bizonyos alapvető jogok, amelyeket különféle ideológiai és politikai irányzatok a saját meggyőződésüknek és érdeküknek megfelelően kívánnak tartalmakkal kitölteni.

Amint a nem korrumpálódott, természetes emberi hajlamokra reflektáló hétköznapi ember természetes értelme az emberi lét céljait és az ahhoz tartozó javakat, előírásokat megérteni képes, ugyanúgy az egyéni és közösségi erkölcsi tapasztalatok bázisán a természetjog vagy a jogfilozófia reflektív tudományos tudása a filozófia és a társadalomtudományok eredményeit is alapul véve - a természeti törvény másodlagos megismeréseként - az emberi természet lényegét, legalapvetőbb tartalmi elemeit és az azokból következő normákat, intézményeket, jogokat és kötelességeket a fogalmak és az azok közötti relációk feltárásával megfogalmazni képes korunkban is. Ezen a reflexiós szinten meg lehet és meg is kell fogalmazni tehát az emberi természet mibenlétét oly módon, hogy abból meg lehessen alapozni, azokból le lehessen vezetni a legalapvetőbb emberi jogokat, kötelességeket és a természetjogi intézményeket. Azért kell azt megfogalmazni, mert az egyéni természetes erkölcsi megismerés során a természeti törvény egynémely alapvető elöírása evidenciaszerüen, vagyis a „hétköznapi megismerés” esetében a természetes hajlam alapján ismerhető meg, amelyeket tudományosan is megalapozva a jogfilozófiai reflexió néhány természetjogi elvet, jogot, normát, intézményt és szabályt a maguk szükségszerűségében tud 
levezetni a közöttük adódó szillogisztikus logikai kapcsolatok kidolgozásával. Ehhez azonban szükségeltetnek a szillogizmus igaz premisszái, amiből néhány az emberi természet vonatkozásában bizton adódik.

Az emberi jogokat az emberiség történetében, ha nem is teljesen kifejtett formában, de voltaképpen a természetjogi érvényesség alapján - „veleszületettként” meghatározva - fogalmazták meg és hirdették ki. (Jelen tanulmányban sokszor nem teszünk fogalmi különbséget a természeti törvény és a természetjog fogalmai között, vagyis azokat legtöbbször szinonimaként használjuk, habár nyilvánvaló, hogy a természeti törvény - tág értelmében - alapozza meg a természetjogot. ${ }^{43}$ ) Az emberi jogok így megalapozást, ha tetszik, igazolást igényelnek a természetjog által mind jogi érvényességüket, mind helyes gyakorlásukat tekintve. Ennek valamiféle intuíciója megvolt a Nyilatkozat megfogalmazásakor, azonban - mint már írtuk - az emberi természet mibenlétét és célját, valamint az ember méltóságának forrását illető egyetértés hiányában a kifejezett természetjogi alapot filozófiai-teoretikus módon nem fogalmazták meg.

Maritain 1947 júniusában, a Nyilatkozat (preambulumának) előkészítése közben írt válaszában úgy fogalmazott, hogy ha Isten nem létezik, akkor csak a „cél szentesíti az eszközt" elv az egyedül észszerü, és ha egy olyan társadalomban alkalmaznák, amelyben végre mindenki jogai teljességét gyakorolná, akkor e cél érdekében bármely ember bármely jogát meg lehetne sérteni, ha az szükséges eszköz lenne a kitűzött cél elérése érdekében. ${ }^{44}$ Elméletileg nagyon is elképzelhető tehát egy, az emberi jogok „teljes” érvényesüléséért küzdő olyan hamis politika, amely a valódi emberi jogokat, s így az emberi méltóságot és az emberi természetet sérti azért, mert az emberi jogokat, azok együttesét nem a helyesen értett emberi természetből eredezteti, amely egyszersmind - egyébként - azok tartalmát is meghatározza.

Maritain nyomán megállapíthatjuk, hogy ez a jogsérelmi helyzet például úgy is elóállhat, hogy a politikai rendszer a helytelen, redukált antropológiából kiindulva az anyagi egyenlőséget materialista alapon és kollektivista módon ${ }^{45}$ abszolutizálja, miközben a szabadságjogokat lábbal tiporja, ahogy az a kommunista diktatúrák esetében történt, de úgy is, hogy a politikai rezsim a legtágabban értett és korlátozhatatlan individuális szabadságjogokat mint egyedül lehetséges jogokat radikalizálja az emberi természet alapvető igazságait figyelembe nem véve. Nézetünk szerint nem feltétlenül kell az Istenben való hit ezek elkerüléséhez, de mindenképpen szükséges a feltétlen értékủ, szellemi természetű emberi lélek adta méltóság elfogadása. Speamann például úgy fogalmaz, hogy a méltósághoz való jog nem egy olyan emberi jog, amelynek

43 Maritain (1985) i. m. (33. lj.) 137.

44 Ld. az idézetet Jean-Yves Calvez: I diritti dell'uomo secondo Maritain. In Vincent Aucante - Roberta Papini (szerk.): Jacques Maritain: la politica della saggezza. Soveria Mannelli, Rubbettino, 2005. 108.

45 Jacques Maritain: Az igazi humanizmus. Budapest, Szent István Társulat, 1996. 44-66. Vö. Turgonyi Zoltán: A marxizmus tomista szemmel. In Frenyó Zoltán - Turgonyi Zoltán: Jacques Maritain. Budapest, L'Harmattan, 2006. 55-97. 
érvényesüléséhez joga van az embernek, hanem az inkább azon alapvető metafizikai indok, amely alapján az emberi lényeknek egyáltalán jogaik és kötelességeik vannak. ${ }^{46}$

Mindezek ellenére Maritain mégis eltekint az emberi jogok ilyen jellegủ és irányú „végső” filozófiai megalapozásától a konkrét politikai cselekvéskor, pontosabban a Nyilatkozat előkészítő anyagához való hozzájárulásakor, minthogy úgy tartotta, hogy az emberi jogok hatékony védelme akkor is biztosítható, ha e jogok érvényességét adó filozófiai (kulturális, vallási, ideológiai vagy politikai) értékalapokban a Nyilatkozat megfogalmazói nem értenek egyet. ${ }^{47}$ Az UNESCO az egyetemes Nyilatkozat előkészítéséhez tett hozzájárulása Bevezetésében, amelynek szerkesztésével Maritaint megbízták, a francia filozófus leszögezte, hogy az emberek egyetérthetnek a Nyilatkozat szövegében úgy, hogy közben nem vallanak azonos nézeteket a végső teoretikus megalapozás kérdésében:

„Teljesen meg vagyok győződve arról, hogy az én, az emberi jogokban és a szabadság ideájában, az egyenlőségben és a testvériségben való hitem igazolási módja az egyetlen, ami szilárdan az igazságra épül. Ez nem akadályoz meg engem abban, hogy egyezzek ezen gyakorlati meggyőződésekben azokkal, akik meg vannak gyöződve arról, hogy az ő igazolásuk - amely teljesen különbözik az enyémtől és ellentétes az enyémmel teoretikus dinamizmusát tekintve - hasonlóképpen csak egyedül az igazságra alapozott." ${ }^{48}$

Azt mondja tehát, hogy a gyakorlati meggyőződések terén egyetérthetnek olyan emberek, akik egyaránt meg vannak győződve arról, hogy az emberi jogok tekintetében csak az ő igazolásuk alapszik az igazságon, miközben ezek az igazságok és végső igazolások egymástól különböznek, illetve egymásnak ellentmondanak. Maritain említett állásfoglalása volt, akit megbotránkoztatott, mások viszont úgy tartották, hogy nem egyszerủ pragmatizmusról van szó, hanem a gyakorlati bölcsesség jegyében tett helyes hozzáállásról.

A Nyilatkozat megfogalmazói nem gondolták viszont, hogy a deklaráció mögött rejlő konszenzus maga teremti meg a jogok érvényességi alapját, hiszen azokat létezőként, azaz érvényesként, „veleszületettként” deklarálják, vagy pedig érződik a megfogalmazásból, hogy úgy jelenti ki a Nyilatkozat az emberi együttélés alapjait, hogy ezen elveket, tartalmakat erkölcsi tényekként kezeli. Maritain hozzáállása egy olyan pragmatikus politikai viszonyulás egy alapvető fontosságú emberi jogi nyilatkozathoz a politikailag gyakorolt igazság, vagyis a gyakorlati igazság bázisán - tehát nem a merő elvtelen pragmatizmus talaján -, ami a jogok deklarálását és érvényesülését

46 Spaemann (2018) i. m. (5. lj.) 33.

47 Ez a gyakorlati helyzet fenn is állt, hisz a Nyilatkozat szövegezői között több nemzetből, kulturális hagyományból és vallásból voltak jelen a nemzetközi közösség képviselői.

48 Jacques Maritain: Introduction aux textes réunis par l'UNESCO. Autour de la nouvelle déclaration universelle des droits de l'homme. In Jacques et Raïssa Maritain: Euvres complètes. FribourgPárizs, Éditions Universitaires - Saint-Paul, 1988. IX. kötet, 1206. 
mint célt tekinti elsődlegesnek. ${ }^{49}$ Csakhogy a kérdés az, hogy e cél beteljesült-e, illetve egyáltalán beteljesülhetett-e az emberi jogokba vetett puszta hit ${ }^{50}$ által akkor, amikor már nem ugyanazon tartalmakat jelentik mindenki számára ugyanazon jogok. Véleményünk szerint: nem. Ennek nemcsak politikai okai vannak, tehát hogy nem érvényesültek sok tekintetben a deklarált jogok, hanem azt is értjük ezen „nem” alatt, hogy teoretikus megalapozatlanságuk hiányában hosszabb távon nem is érvényesülhettek, mert az emberi jogok megfogalmazott „emberi természet” nélkül voltaképpen nem is emberiek, és nem is jogok a szó szoros értelmében. A természeti törvény elsődleges, „természetes hajlam” alapján való megismerésének szintjén a Nyilatkozatban deklarált jogok empirikusan egybeesnek a - Szent Tamás-i értelemben vett - természeti törvényen alapuló elöírásokkal, de a további megismerésben, kifejtésben, értelmezésben (szintén a Szent Tamás-i tan szerint) adódhatnak helytelen és kedvezőtlen kulturális-társadalmi folyamatokkal magyarázható deformációk, amit csak erősít az, ha a természeti törvény teoretikus, másodlagos megismerése, azaz annak és az azokból fakadó jogok megalapozása és kifejtése hiányt szenved.

\section{A méhmagzat emberi lényegéből, méltóságából fakadó életjoga - a pandektista örökség meghaladásának szükségessége}

Egy alapvető fontosságú nemzetközi emberi jogi dokumentum tárgyalásával kezdtük e tanulmányunkat, azonban az emberi magzat élethez való jogát érintően egy jóval korábban meggyökeresedett jogi gondolkodásmód foglyai maradtak a kulturálisan a német pandektista gondolkodásmód jegyeit mutató jogrendszerek jogászai. Márpedig a méhmagzat létét s így az élethez való jogát alapvetően e kontextusban tárgyalták a polgári jogi gondolkodásban, sőt, mint majd látni fogjuk, nem egyszer az alkotmányjogi szemléletmódban is, azon alkotmánybírák esetében, akik e polgári jogi szemléletmódot vitték magukkal az alkotmányos diskurzusba és alkotmánybírósági döntéseikbe. De nézzük meg, hogy milyen ez a szemléletmód, amely még az egyetemes emberi jogi nyilatkozatok s az azoknak megfelelő alkotmányok jogi emberképét is képes a mindennapokban felülírni akár új módon is, hogy az alkotmányok értelmezése vagy módosítása, egészen kivételesen egy új alkotmány elfogadása esetén a hagyományos pandektista polgári jogi szemléletmód szabja meg az alkotmányos tartalmat a méhmagzat alapvető jogi státusza, alanyisága vonatkozásában. A teoretikus feladat pedig éppen az lenne, hogy a pandektista jogképesség-fogalmat végleg magunk mögött hagyjuk a méhmagzat alanyiságának, emberi személy voltának és élethez való jogának elemzésekor, minthogy az teljességgel inadekvát annak fogalmi megragadására.

49 Calvez i. m. (44. lj.) 108-109.

50 Bár az emberi jogok racionális megalapozásukat elveszítették, attól még nem tűnt el vallásos jellegük, sőt az emberiség vallásává váltak. Ha meg akarják menteni az emberi jogok egyetemességét, akkor egyfajta hitbeli megalapozással kell rendelkezniük, az emberi méltóság szentségébe vetett laikus hitté kell átalakulniuk - írja Viola. Francesco Viola: Diritti dell'uomo, diritto naturale, etica contemporanea. Torino, G. Giappichelli, 1989. 80. 
A pandektisztikában azon problémát, hogy mi teszi az alanyt képessé arra, hogy személy legyen jogi értelemben, úgy oldják meg, hogy személy a jogalany, vagyis a polgári jogi értelemben vett személy az, aki jogoknak (és kötelességeknek) lehet a címzettje. Azt a képességet, hogy jogoknak és kötelességeknek lehet a címzettje, nevezik polgári jogi jogképességnek (bürgerliche Rechtsfähigkeit). Ennek előfeltétele, hogy egyfajta status naturalisszal rendelkezzen, amely akkor válik valóra, ha élve születik és emberi (arccal) kinézettel rendelkezik. ${ }^{51}$ Az emberi lény tehát azért és annyiban jogalany, ha azt az állam elismeri. A pandektisztika szerint a jogképesség teszi az embert személlyé, jogalannyá (Rechtsperson), akinek (jogi értelemben vett) személyisége van. Ez azon állítás logikai szerkezetében is tetten érhető, miszerint „minden ember jogképes, ezért személynek minősül” (Alle Menschen sind rechtfähig, sie sind damit Personen), vagy egy másik megfogalmazás szerint: Person im rechtlichen Sinne ist der Mensch, der rechtsfähig ist, vagyis a személy jogi értelemben az az ember, aki jogképes.

A jogi (értelemben vett) személyiséget (Rechtspersönlichkeit) a jogképesség adja, így ez utóbbi maga a személyiség. A jogi személyiség és jogképesség ily módon egybeeső fogalmak. A képesség azonban akkor jogi (s lesz jogképességgé, valóban létezővé), ha a törvény azt juttatja, s egyben tartalmát is meghatározza. Míg a felvilágosult modern természetjogi felfogásban az embert eredendően, természeténél fogva megilletik bizonyos veleszületett természetes jogok - aminek eszmetörténetileg megállapítható módon keresztény gyökerei vannak -, vagyis az ember e jogok címzettje természeténél fogva, vagyis $a b$ origine, addig a pandektisztikában az ember úgy gyakorolja jogait, hogy előzetesen az állam neki jogképességet tulajdonított, ekképpen az így általa gyakorolható jogok a jogképességtől függenek. Míg a felvilágosodott természetjogban az ember méltóságát veleszületett jogai alapján bírja, addig a pandektisztikában ezen méltóság az állam által juttatott jogalanyiságon alapszik, amelynek érvénye független a ténylegesen élvezett alanyi jogoktól, minthogy ezen utóbbiak egy további törvényi, azaz állami akarattól függő juttatástól függenek. ${ }^{52}$ Következésképpen nem a jogoké az ügydöntő szerep a jogképesség tekintetében, hanem annak állami juttatásáé, miáltal ez utóbbi az embert az államhoz való viszonyában meghatározó jogi minőséggé válik.

Mivel az állami juttatást megelőzően az ember nem rendelkezik jogi minőséggel, így az embernek nincs is az állammal szemben érvényesítendő, jogalanyiságához, a jogi értelemben vett személyiségének, a jogképességének az elismeréséhez való természetes alanyi joga. A pandektisztikában a jogképesség tehát annyiban van, amennyiben azt a törvények juttatják, amelyek egyben annak tartalmát is specifikálják. A pandektisztika szerint ugyanis a jogképesség az állami szuverenitás egy fragmentuma, amelynek a polgárai részére való juttatásával az állam a szuverenitásának gyakorlásában önkorlátozást gyakorol. Ily módon a polgárjog alapfogalma, a jogképesség, közjogi kategória. Márpedig ha a jogképesség minden további alanyi jog

51 Alberto Donati: Giusnaturalismo e diritto europeo, human rights e Grundrechte. Milánó, Giuffrè, 2002. 177-178.

52 Uo. 181-182. 
megszerzésének és gyakorlásának az előfeltétele, akkor annak közjogias jellege áthatja a teljes polgári, azaz a magánjogot.

E felfogásban tehát egy alanyi jog juttatásának előfeltétele a jogképesség megléte, vagyis az, hogy az emberi személy jogalany lett. A pandektisztikában a jogi személyiség, azaz a jogalanyiság nem egy általános alanyi jog, hanem pusztán csak egy képességet, alkalmasságot jelent jogosultságok címzettjének lenni. ${ }^{53} \mathrm{Nem}$ lehet ugyanis önmagában vett jog az, ami minden jog alkotóelemét képezi. A szerződési, a végrendelkezési és a házasodási képesség nem a jogképességnek, illetve nem az emberi személy általános fogalmának a folyományai, hanem az állam attribúciói, juttatásai. A fizikai személy ekképpen a jogképesség formális fogalmához és azon keresztül az államhoz kötött. ${ }^{54} \mathrm{Az}$ állam juttatja az egyes jogokat az elözetesen elismert, juttatott jogképesség és jogalanyiság alapján. A jogképesség nem jog, hanem egy puszta státusz. A jogképesség az előbb kifejtettek alapján a pozitív, vagyis a politikailag tételezett jogon alapszik, és így az állam által adományoztatik. ${ }^{55}$ Ebből következik, hogy annak nincsen saját ontológiai státusza. Így az is lehetséges, hogy az állam úgy dönt, hogy nem juttatja a jogképességet az emberek egy meghatározott csoportjának, s így azoknak nem lesznek jogai.

Általánosabb érvénnyel is kijelenthető, hogy a kortárs kontinentális jogrendszerek - részben a fenti logika alapján - a méhmagzatot jobbára indirekte, feltételes, azaz az élve születéstől függő helyzetben levő és részleges jogképessége miatt egyfajta kvázi embernek tekintik csupán. Ily módon a születendő ember nem emberi személyként eleve jogalany, aki így jogképessége birtokában jogoknak és kötelességeknek lehet a címzettje, például örökösnek nevezhető, hanem a gondolkodásmódot tekintve mintha éppen fordítva állnának a dolgok a német pandektisztikából örökölt jogpozitivista megközelítésben: mivel egyes vagyoni jogok címzettje lehet, például örökösnek nevezhető, s ezért szerzőképessége van, így induktíve megállapítható, hogy jogok és kötelességek címzettje lehet, amiből következik, hogy feltételesen (a szerzőképességének valószínű érvényesülésétől függően) jogképessé nyilváníttatik, és ezért - ilyen relatív és részleges terjedelemben ${ }^{56}$ - jogalany, viszont nem a jog számára ab origine

53 Donati i. m. (51. lj.) 183.

54 Francesco D. Busnelli: Rilevanza giuridica della vita prenatale, categorie civilistiche, principi costituzionali. In Donato Carusi - Silvana Castignone (szerk.): In vita, in vitro, in potenza: lo sguardo del diritto sullembrione. Torino, Giappichelli, 2011. 27.

55 A jogi normapozitivizmus szélsőséges képviselőjénél, Hans Kelsennél a jogalany nem olyan centrummal, azaz méltósággal rendelkező entitás, amely egyes szám első személyben maga áll a normák rendszere előtt, hanem akinek a normák adják a megszemélyesített, fiktív, virtuális létet, minthogy úgy érzékelik és egyben teremtik őt mint meghatározott normatív beszámítások egységes pontját. Míg a kanti jogfelfogás és a pandektisztika feltételezi az alany létét, és az a kérdés merül fel, hogy mikor lesz az jogi, addig a Tiszta jogtan megfordítja a kérdést, s azt kérdezi, hogy igaz-e, hogy a jogalany valóban alany. Massimo La Torre: Disavventure del diritto soggettivo. Milánó, Giuffrè, 1996. 399. A kelseni felfogás tehát a természetes személyt mint a tárgyi „normakomplexum” megszemélyesítését tekinti, ami tehát jogilag nem ember. Hans Kelsen: Tiszta jogtan. Budapest, ELTE Bibó Szakkollégium, 1988. 32.

56 Vö. Fritz Fabricius: Relativität der Rechtsfähigkeit. Ein Beitrag zur Theorie und Praxis des privaten Personenrechts. München-Berlin, Beck, 1963. 
személyiséggel rendelkező emberi személy. Mivel nem biztos, hogy tud majd szerezni, mivel előfordulhat, hogy nem éli meg a megszületését, ezért nyilvánítja a polgári törvénykönyv, azaz az állam alkotta pozitív jog csak féltételesen jogképesnek. Úgy tünik, hogy a szerzőképességből fakadó (részleges és feltételes) vagyonjogi jogképesség teszi tehát az embert személlyé polgári jogi értelemben. ${ }^{57}$

A szemlélet többek szerint a római jogig nyúlik vissza, ahol a méhmagzat nem volt személy, és jogképessége is - szerzőképességében megmutatkozva - az élve születéstől függően (függő jogi helyzetében) feltételes volt. ${ }^{58}$ Mindezen jogtörténeti és kulturális örökség mellett, illetve azon túl nem egy esetben a potencia/potencialitás (képesség/lehetőség) arisztotelészi fogalmának ${ }^{59}$ helytelen alkalmazása a méhmagzat (jog) alanyiságára okoz korunkban is téves gondolkodásmódot, aminek eredményeképpen többen - az alkotmányjogi érvelésre is kiható módon - az emberi személyt méhmagzati korában csak „potenciális embernek” tekintik. Meg kell azt is említeni, hogy a filozófiai perszonalizmus is az „igazi”, azaz a voltaképpeni, kiteljesedett emberi személyt szükségképpen a (felnőtt) személyben megtestesülő morális és társas lényben ragadja meg, aki morálisan kiteljesíti a személyközi emberi kapcsolatait, s ezáltal lesz azzá, akivé válnia kell.

A magyarországi 1989/90-es politikai rendszerváltás után felállt - számos hívő keresztény, jobbára katolikus tagot soraiban tudó - Alkotmánybíróságunk abortuszdöntéseinek többségi véleményében azonban kétségtelenül a magyar jogi gondolkodásmódot meghatározó német pandektista jogképesség-koncepció tükröződött vissza. A német pandektisztikából örökölt - és onnan több kontinentális ország jogrendszerében elterjedt, már ismertetett - felfogás, miszerint a fizikai személy jogi létét meghatározó, formális fogalomként tekintett jogképesség nem természetes alanyi jog, hanem az állam által juttatott puszta státusz, mintha fennmaradt volna jogrend-

57 A szemlélet, miszerint a méhmagzatnak az élve születésig feltételes a jogképessége és a szerzőképessége, a római jogból származtatott ránk. Ld. Umberto Vincenti: Diritto senza identità, la crisi delle categorie giuridiche tradizionali. Róma-Bari, Laterza, 2007. 38.

58 E felfogás szerint a méhmagzatot fikcióval tekintették személynek (feltételesen jogképesnek), s szerintük az nem volt személy, de úgy tettek - érdekei, különösen szerzési érdeke védelmében - mintha az volna. Az ezzel ellentétes, jóval meggyőzőbb, s ezért általunk is osztott szakmai áláspontot a katolikus római jogász Wolfgang Waldstein képviseli. Wolfgang Waldstein: A szivébe írva. A természetjog mint az emberi társadalom alapja. Budapest, Szent István Társulat, 2012. 132-139.

59 Ehelyütt megtalálható némely olyan szerző munkáinak elemzése, akik - bár különböző mértékben és módon - az elmúlt évtizedek bioetikai vitáiban a potencialitás érvét használták: Maurizio Mori: Il feto ha diritto alla vita? Un'analisi filosofica dei vari argomenti in materia con particolare riguardo a quello di potenzialità. In Luigi Lombardi Vallauri (szerk.): Il meritevole di tutela. Giuffrè, Milánó 1990. 735-839.; Anne Fagot-Largeault: L'embryone umano come persona in potenza. In Evandro Agazzi (szerk.): Bioetica e Persona. Milánó, Franco Angeli, 1993. 158-174.; Anne Fagot-Largeault: The Notion of the Potential Human Being. In David R. Bromham - Maureen E. Dalton - Jennifer C. Jackson (szerk.): Philosophical Ethics in Reproductive Medicine. Manchester, Manchester University Press, 1990. 149-155.; Anne Fagot-Largeault: Abortion and Arguments from Potential. In Raanan Gillon (szerk.): Principles of Health Care Ethics. London, Wiley, 1993. 577-586.; Emanuele Severino: Essere uomo „in potenza”. In Emanuele Severino: Nascere e altri problemi della coscienza religiosa. Rizzoli, Milánó, 2005. 139-142. Emanuele Severino: Discussioni sulla potenza e l'embrione. In Emanuele Severino: Sull'embrione. Rizzoli, Milánó, 2005. 51-57. 
szerünk dogmatikájában is, így szükségképpen jelen volt az alkotmánybíróvá vált, jobbára polgárjogász jogtudósok gondolkodásában is. Ez a méhmagzat jogképessége tekintetében azt eredményezte, hogy a mindennapi jogélet által szükségesnek ítélt szerzőképességét, öröklési vagyonjogi képességét elismeri az állam, de az ezek alapjául álló jogképességet teljesen csak akkor, ha élve születik, igaz, akkor „visszamenőleg” a fogamzásának időpontjától kezdve.

A lényegét tekintve a jogképesség formális kategóriájának juttatásával az állam dönti el, hogy a jog számára mely ember fizikai személy, s a magzat esetében - azaz minden ember fejlődésének legelején - az a születés tényéhez kötött. Voltaképpen tehát e jogrendszerekben a jogképesség állam által juttatott formális kategóriáján keresztül s a vagyoni (örökösi) jogok juttathatóságainak megfontolásaiból került szabályozásra a méhmagzati státusz a polgári jogban, s a méhmagzatot is így érzékelik e jogrendszerekben, jogi státuszában a születés tényéhez kötötten. ${ }^{60} \mathrm{Az}$ élve születés tényéhez kötött végérvényes és teljes (visszaható hatályú) jogképesség az emberi élet 19. századból vagy még régebbről örökölt orvosi-biológiai tudásbázisához igazodott és annak hétköznapi közgondolkodását viselte magán, tudniillik akkor fog „igazán élni" a megfogant és fokozatosan növekvő baba, ha már élve megszületett, amenynyiben tehát „túlélte a születést”, és már szabad szemmel is látható. Az anyaméhben való fejlődés egy adott időpontjában így nem lehet tudni, hogy a méhmagzati ember jogképes-e, vagy sem, tehát voltaképpen azt, hogy tulajdonképpen ember-e, vagy sem. Azonban a személy fogalmából kiindulva azt kell, hogy mondjuk, hogy az ember a méhmagzati állapotában is jogképes, mert jogalany, vagyis mert emberi személy, de ettől még lehet, hogy azért nem realizálódik majd szerzőképessége, mert később meghal, esetleg a születéskor vagy közvetlenül elötte.

A polgári jogi, illetve a más jogági emberfogalmakat, jogképesség-fogalmakat kellene a helyes látásmódot tartalmazó Nyilatkozat 6. cikkelyében megfogalmazott jogalanyiság elismeréséhez foglalt alapvető emberi joghoz igazítani, illetve azokat az ennek megfelelő alkotmányokban foglalt alkotmányos emberfogalomhoz lenne szükséges igazítani, minden emberi személy egyenlő és feltétlen méltóságából kiindulva. Csak egyetlen és egységes jogi emberfogalom létezik, ez pedig a természetes személy természetjogi értelemben vett személyfogalmán kell, hogy alapuljon, abból kiindulva, hogy az ember szellemi lelke révén eleve méltósággal és alapvető emberi jogokkal rendelkező személy. Egy ilyen jogi személyfogalom bázisán a méhmagzatot már nem lehetne nem személynek, nem jogalanynak tekinteni. A katolikus, helyes

60 A már hivatkozott Francesco Busnelli így fogalmaz: „la persona fisica è legata al concetto formale della capacità giuridica, e per questo tramite allo Stato. Lo Stato stabilisce chi è "persona fisica « e chi non lo è; e ciò fa parametrandosi sulla nascita per ragioni evidenti, che stanno nell'orientamento del codice, nella sua chiara finalizzazione alla disciplina dei rapporti patrimoniali. (A fizikai személy a jogképesség formális fogalmához és ezért ezen keresztül az államhoz kötött. Az állam határozza meg, hogy ki „fizikai személy”, és ki nem az, s ezt a kódex irányultságából fakadóan, minthogy világosan a tulajdonjogi viszonyok szabályozására irányul, evidens okokból a születéshez kötve teszi.) Busnelli i. m. (54. lj.) 27. A szerző a patinás Unione Giuristi Cattolici Italiani, az olasz katolikus jogászegylet tagja 1963 óta. 
szemléletű - jobbára olasz - jogászok a jogképesség kontinentális (német pandektista) értelmét tekintik a méhmagzat emberiszemély-létének, s így mindenekelőtt az életéhez való joga elismerése legnagyobb kerékkötőjének. Mi is ezen a véleményen vagyunk.

Az állam e formális kategórián keresztül a jogi képességgyakorlás effektivitásának, azaz ténylegességének szempontjait érvényesíti akkor, amikor a személyt voltaképpen tulajdonosnak tekinti, mégpedig olyannak, aki nem magatehetetlen, hanem éppen hogy cselekedni képes a jogviszonyokban a maga javára, különösen, hogyha tulajdonos polgárként tehetôs. Ez a facultas agendi, avagy a jogképesség, a német Vermögen, amiben nem véletlenül benne rejlik - írja Ernst Bloch - a jogképesség alapja, a pénzben kifejezhetö vagyon mint "tehetösség”. ${ }^{61} \mathrm{Az}$ így értett facultas agendi mint jogképesség az alanyi jog lényege. Vagyis az jogképes, akinek lehetösége van a cselekvésre (hitelezőként, kereskedőként), s ez a lehetőség a tehetősséggel, a vagyonnal való rendelkezéssel van szoros kapcsolatban. Érzékelhető, hogy a fizikai személy jogi léte a polgárjogban a tulajdonos polgár képére lett szabva a polgárjogi kódexekben. Annyiban létezik az alany, a „fizikai személy” a jog számára, amennyiben az tulajdonolni képes, s mivel erre minden megszületett ember képes, ezért az alanyként létezik a polgári jogban, minthogy a formális jogképességet az előbbiek miatt elözetesen megkapta az államtól.

A katolikus emberkép ezzel szemben az emberben, minden emberben a szellemi lelket $\mathrm{s}$ az abból fakadó feltétlen méltóságot tiszteli a fogantatásuktól kezdve. A tisztelet aktív és kompromisszum nélküli jogvédelmet involvál e legalapvetőbb emberi természetjog vonatkozásában. Azért természetjog, mert az ember szellemi lelke az emberi természeti lényeget, az emberi személy mivoltot adja, ${ }^{62}$ amely az emberben így a legfóbb emberi minöség hordozója, s amely teljesen egyedi testben van jelen a fogantatástól kezdve. Aki így az ember elpusztítására tör az emberi embrióban, az a legnagyobb bűnt, a gyilkosságot követi el a konkrét ember és közvetetten az egész emberiség ellen. E szemléletmód mint természetjogi igazság elfogadtatásáért küzdenek a katolikus jogászok, de immáron nehezített terepen, hiszen időközben számos új bioetikai problémával találták magukat szembe a mesterséges megtermékenyítés különböző módozatai kapcsán, amelyeket a legújabb biotechnológia lehetővé tett.

61 „Das subjektive Recht, das einer in dieser Fassung hat, ist das Recht, das einer auf etwas hat, der Anspruch, die Forderung, die Berechtigung. Es ist facultas agendi oder rechtliches Vermögen, wobei nicht ohne Grund jenes Vermögen, das in Geldwert ausdrückbar ist, anklingt." (Az alanyi jog, amellyel az egyén ebben a felfogásban rendelkezik, az a jog, amellyel az egyénnek joga van valamire: az igény, a követelés, a jogosultság. Ez egy facultas agendi vagy jogképesség, amely azonban nem ok nélkül emlékeztet a pénzben kifejezhető vagyonra.) Ernst Bloch: Naturrecht und menschliche Würde. Frankfurt, Suhrkamp, 1961. 239.

62 „Io sono tutto individuo in ragione di ciò che mi viene dalla materia, e tutto persona in ragione di ciò che mi viene dallo spirito." (Teljesen egyén vagyok a tekintetben, ami bennem az anyagból ered, és teljesen személy abban a vonatkozásban, ami bennem a lélekből jön.) Jacques Maritain: La persona e il bene comune. Brescia, Morcelliana, 1998. 26. „Ma ognuno di noi è anche una persona, e in quanto persona non è sottomesso agli astri, sussiste intiero della sussistenza stessa dell'anima spirituale, e questa è in lui un principio di unità creatrice, d'indipendenza e di libertà." Uo. 23. 
Az újabb alkotmányok az ember vonatkozásában emberi személyről szólnak, ami - azokhoz csatlakozunk, akik szintén ezt vallják - tudatos szakítást jelent a polgári jogi kodifikációk formális szemléletmódjával, amelyeknek a jogképesség a kulcskategóriája, továbbá a fizikai személy és a jogi személy dichotómia. ${ }^{63} \mathrm{Ez}$ a személy azonban, ha adott esetben eredőiben a perszonalizmus filozófiájában gyökerezik is, lényegét tekintve a kapcsolataiban kiteljesedő személyiséget fedi (lásd például a gazdasági, a szociális és a kulturális jogokat), amely nem segít minket a méhmagzati személy státuszának megértésében. ${ }^{64}$ Ez a felfogás azt vallja, hogy az ember nem személy, hanem erkölcsi és emberi jogi imperatívuszait megélve válik felelős, racionális és öntranszcendens, kapcsolataiban megvalósult szabad személlyé, személyiséggé. ${ }^{65}$ Azért kell, hogy kinyilvánított és érvényesített jogai legyenek, hogy személyként megvalósulhasson. Az újabb katolikus perszonalizmus viszont már az emberi személy belső lényegi elemére is jobban koncentrál, megkülönböztetve ôt már a magzati stádiumában is a dolgoktól, s ez megközelítés a méhmagzat emberi személy jellegét is jobban képes már megragadni ${ }^{66}$ miközben a jogszabályok még jelenleg is dologi jogi fogalmakkal operálnak az emberi embrió esetében. ${ }^{67}$

A katolikus morál- és jogfilozófiai reflexió filozófiai antropológiai teoretikus eredménye az - amelyet egyébként minden józan és elfogulatlan reflexió belátni képes -, hogy emberi személy és ember mivolt, emberi személyiség, alany és alanyiság az emberben, valamint a fizikai (emberi) személy fogalmai nem választhatók szét, s egyik sem hiányozhat, minthogy mindegyik az emberi személy egy és ugyanazon valóságát fedi a fogantatástól kezdve egészen a halálig. Az ellentétes kortárs jogi teoretikus törekvések éppen arra irányulnak, hogy ezeket fogalmilag szét-, illetve leválasszák egymástól, s bizonyos attribútumokat ne tulajdonítsanak a méhmagzati személynek. Például amikor azt állítják egyes jogászok, hogy a méhmagzat rendelkezik valamiféle alanyisággal, de nem személyiséggel, illetve hogy valamiféle emberi jelleggel biológiai

63 Busnelli i. m. (54. lj.) 27.

64 Bár a méhmagzat ebben a méhen belüli állapotában is már kapcsolatban van többféle módon is az édesanyjával, nem azért létezik filozófiai értelemben, mert kapcsolatban van vele, hanem mert létezik, ezért tud édesanyjával kapcsolatban lenni - az már más kérdés, hogy ha nem lenne vele biológiailag kapcsolatban, akkor normális, azaz nem mesterséges körülmények között nem tudna tovább élni sem.

65 Lauriola i. m. (12. lj.) 145.

66 Robert Spaemann: Persone. Sulla differenza tra "qualcosa” e "qualcuno". Róma-Bari, Laterza, 2005; Giorgio M. Carbone: L'embrione umano. Qualcosa o qualcuno? Bologna, Studio Domenicano, 2014; Possenti i. m. (29. lj.) 134.; Josef Seifert: Essere e persona. Verso una fondazione fenomenologica di una metafisica classica e personalistica. Milánó, Vita e pensiero, 1989. Josef Seifert hatásosan mutatja ki az emberi embrió szellemi-racionális lelkével igazolt, fogantatásától való emberi személy voltát s abban gyökerező ontológiai immanens méltóságát: Josef Seifert: Essere e persona. I fondamenti filosofici del personalismo. Philosophical News, 2014. november 9. 88. Elérhető: www.philosophicalnews.com/wp-content/uploads/2017/07/9.10.pdf (A letöltés dátuma: 2020. 10. 02.)

67 „[A]z egészségügyi törvény dologi jogi fogalmakkal operál az emberi embrió tekintetében is.” Navratyil Zoltán: A varázsló eltöri pálcáját? A jogi szabályozás vonulata az asszisztált humán reprodukciótól a reproduktív klónozásig. Budapest, Gondolat, 2012. 248. 
értelemben bír, de amiből csak - valamikor - később lesz az emberi személy a jog alanyaként, saját jogainak hordozójaként.

Ezzel szemben az a helyzet, hogy amikortól az emberi személy megfogant, egészen addig, ameddig él, végtelen és feltétlen erkölcsi értékkel bíró emberi személy, akinek lényegét a mindenkiben meglevő és elveszíthetetlen szellemi lelke adja, s nem pedig az effektív vagy potenciális észhasználata, erkölcsi döntési képessége vagy bármely más funkciógyakorlása. Úgy tünik, hogy az ember halála kapcsán már ezt egyre inkább érzékeli az emberiség, míg a méhmagzat esetében ugyanennek észlelésére még további teoretikus lépéseket kell tenni, hogy az előbbieket teljes mértékben belássuk és elfogadjuk. Fel kell tehát fedezni azt, hogy a méhmagzat nem csupán valamiféle alanyisággal vagy emberi jelleggel rendelkezik, hanem hogy ő teljes értékű individuális, azaz egyedi emberi személy, teljesen egyedi testben és (erkölcsi) szellemi lélekkel.

A felmerülő jogi kérdés voltaképpen a körül az elvi megfontolás körül forog, hogy mi adja végeredményben az ember lényegét (jog)filozófiai értelemben, s hogy ezzel a minőséggel az emberi magzat rendelkezik-e. Ha ugyanis valami valóban lényegi ismérv, akkor annak mindvégig jelen kell lennie az emberben, amíg ő él, ha viszont nem az, hanem csupán járulékos vagy éppen nem annyira esszenciális elem, akkor annak hiánya, részleges jelenléte vagy éppen kialakulatlansága (még csak potenciális jelenléte) nem hathat ki az ember ember voltára semelyik életállapotában, így a méhmagzati korúéban sem. Az ember lényegi mivolta mibenlétére vonatkozó kérdésre a hagyományos válasz az szokott lenni (értékelvü, morálfilozófiai tekintetben konzervatív körökben is), hogy az ember értelmes, vagyis Homo sapiens volta az az elem, amelylyel minden ember mint ember rendelkezik, így a magzati korú emberi lény is - még ha csak potenciális módon is. Csakhogy ezzel szemben felvethető, hogy csak anynyiban lenne a magzati korú ember emberi személy, amennyiben majd gondolkodni fog tudni, illetve - annak legmagasabb szintủ lelki kifejeződéseként - reflektálni fog majd tudni saját élete értelmére? Amíg ez meg nem valósul, addig az emberi embriók és magzatok csak „potenciális személyek” lennének, akik bár nem személyek, mégis - jog- és értékvédelmi biztonsági megfontolásokból - akként kezelendők?

De mi a helyzet azon emberi magzatok esetében, akik sohasem fognak tudni gondolkodni, vagy mert korábban meghalnak, vagy mert az ahhoz szükséges agyi, központi idegrendszeri szervi alappal (agyvelővel az anenkefália esetében) genetikai sérültségük okán nem - vagy a funkciógyakorláshoz nem elégséges mértékben, azaz csak részben - rendelkeznek, és (rövid) életük során nem is fognak soha rendelkezni? Ők így sohasem lesznek és soha nem is voltak a szó szoros, igazi értelmében vett emberi személyek? Nyomatékosítjuk, hogy a célunk nem speciális esetek morál- és jogfilozófiai státuszának meghatározása, hanem az emberi személy helyes fogalmi megragadása, amelynek megválaszolásától, pontosabban annak eredményétől a jog művelői sem tekinthetnek el. A megalapozó érvelés, jellegét tekintve, amelyre minden alkotmánybíróságnak és a rendes felsőbíróságnak szüksége van, jogfilozófiai jellegü. A konklúziót azonban az alkotmányjog és általában a tételes jog képviselői vallhatják, sőt vallaniuk kell, minthogy a jogfilozófia e tekintetben a minden ember- 
ben meglevő természetjogilag azonosat határozza meg, amely alapján az (alkotmány) jogászok minden embert, így a méhmagzat korút is a többi (felnőtt) emberrel azonosnak, lényegileg egyenlőnek kell, hogy tekintsék.

Ha valaki nem tekinti a méhmagzatot embernek, akkor az a lehetőség marad a számára, hogy az emberi életet valamiképpen biológiai értelemben tekintse emberinek, de nem személyinek, azaz még nem emberi személyhez tartozónak. Ekkor azonban meg kellene határozni azt az időpontot, amelyben az a minőségi biológiai (?) változás, fejlődési pont áll be, amikor ez az emberi jelleget hordozó biológiai szubsztrátum már (hirtelen) személlyé lesz a jog számára is ${ }^{68}$ Nyilvánvaló, hogy ilyen biológiai stádium nem határozható meg, mert annak puszta bekövetkezte folytán ilyen metafizikai (vagy: metabiológiai) jellegủ minőségi (azaz a biologikumot meghaladó) fordulat nem állhat be. Anélkül, hogy mélyebb bioetikai kérdésekbe bocsátkoznánk, annyit megállapíthatunk, hogy amennyiben az emberi lét meghatározott biológiai, illetve fiziológiai aspektusára, nem lényegkonstitutív elemére szorítjuk az emberi személy fogalmát, például a fejlett központi idegrendszer kialakultságának és működésének kritériumára, mondjuk a tudat vagy öntudat meglétére, akkor lehetnek, lesznek olyan természetes személyek, emberek, akik e megközelítésben „még nem” vagy „már nem” személyek.$^{69} \mathrm{E}$ szemléleti módnak beláthatatlanok az emberellenes következményei, ${ }^{70}$ amennyiben az a jogi közgondolkodásban széles körben elterjed, illetve ha a jog alkotói (jogalkotók, bírák) azt magukévá teszik.

A gyakorlat sajnos már tömegesen mutat fel ilyen példákat a fejlettnek, magasan civilizáltnak tekintett nyugati országokban. Gondolunk itt például a dobogó szívü, de agyhalottnak nyilvánított „szívdonorokra”, amely gyakorlat nyilvánvalóan csakis emberölésnek minősülhet. ${ }^{71}$ Ezen, „csúszós lejtö” effektusként minősülő folyamattal szemben különösen szükségessé válik - alapjogvédelmi megfontolásokból - az emberi személy olyan lényegi, ontológiai jellemzőit meghatározni, amelyek nem esetlegesen vagy különböző mértékben vannak meg az egyes emberekben, hanem a személyfogalom lényegénél fogva. Ezen lényegi ismérvek az embert létének minden momentumában jellemzik a fogantatásától kezdve, s csak akkor szűnnek meg a konkrét ember esetében fennállni, ha már a fogalommal jelzett entitás, azaz maga a konkrét adott ember már nem létezik, mert meghalt. Nem lehetnek azok tehát potenciálisak vagy félig meglévők, mert az entitás éppen e lényegi ismérveinél fogva, azok megléte folytán van, vagy éppen azok hiányában (már) nincs, vagy nem is létezett

68 Vittorio Possenti a humánembrió jogállását és személy voltát elemzi a fentiek szerint. Possenti i. m. (29. 1j.) 132-133.

69 Uo. 133.

70 Ignazio Lagrotta így fogalmaz: „Hasonlóképpen teljességgel önkényesnek tűnik azon felfogás, amely az emberi személynek mint az élethez való jog alanyának a kezdetét az öntudatnak az egyénben való ébredéséhez köti, mivel az aberrált következményekre vezet, mint például annak lehetőségére, hogy ne tekintsék embereknek azon egyéneket, akik értelmi fogyatékosokként születtek." Ignazio Lagrotta: Il diritto alla vita e i diritti fondamentali dell'embrione. In Antonio Tarantino (szerk.): Culture giuridiche e diritti del nascituro. Milánó, Giuffrè, 1997. 135. 
soha. A lényegi ismérv éppen azt jelenti, hogy az adja azon valóság specifikus létét, létezését, természeti esszenciáját. Az előbbieket is figyelembe véve azt kell mondanunk, hogy az emberi egyén, minden egyén a fogantatásától fogva lényegénél, azaz szellemi lelke folytán sérthetetlen méltóságú emberi személy, mégpedig jogi értelemben is, s ezért jogalany.

\section{Az embrió és a (felnőtt) ember úgy viszonyulnának egymáshoz, mint a makk a tölgyfához?}

Az általunk helytelennek tartott, de a nemzetközi morálfilozófiai diskurzusban nagy hatást gyakorolt álláspontok közül említenünk kell Michael J. Sandel analógiaérvét, amelyet egyébként Robert P. George már hatásosan megcáfolt: eszerint az emberi embrió és az ember között ahhoz hasonlatos lenne a különbség, mint ami a makk és a belőle kifejlődő terebélyes tölgy között áll fenn. Sandel számos - egy kötetnyi - kiváló érvet hoz a génmanipuláció ellen, ${ }^{72}$ azonban, amikor az emberi embrió státuszát kell meghatároznia, helytelen példát hoz, ami mutatja, hogy voltaképpen nem lényeglátó, azaz jogfilozófiai e tekintetben a megközelítése. (Sandel máshol is ugyanezen hasonlattal élt.) ${ }^{73} \mathrm{~A}$ hasonlat szerint az, hogy a házunk előtt álló fán a mókus megeszik egy makkot, nem ugyanolyan természetü dolog, mint amikor egy terebélyes tölgyfát dönt ki a vihar. ${ }^{74}$ Amiképpen a makk és a tölgyfa más jellegü dolgok, úgy az emberi embrió és az ember is, habár az előbbiekből lesznek az utóbbiak. Majd az írja, hogy az emberi élet fokozatokon keresztül fejlődik ki.

Sandel azt állítja, hogy amiképpen a makk nem tölgyfa, úgy az emberi embrió sem emberi lény. George helyesen mutat rá azonban arra, hogy ez az érv azért hibás, mert alapfeltételezésként abból indul ki, hogy az emberi embrió nem rendelkezik alapvető értékkel vagy méltósággal, s így az embrionális kutatás anyagának státuszában van. Már ott félrecsúszik az érvelése - mutat rá George -, amikor az összehasonlító elemeket kiválasztja: a makk az emberi embrióval, a tölgyfa az emberrel lenne analógiába állítható. Csakhogy, írja George, a tudomány által teljességgel kimutatott - és Sandel által is elismert - folyamatos fejlődést tekintve a tölgyfával nem maga az ember, hanem az érett ember, vagyis a felnőtt állítható párhuzamba. ${ }^{75}$ Természetesen Sandel párhuzamának kétségtelenül van egyfajta érzékelhető hatásossága, hiszen mindanynyian valóban veszteséget érzünk, ha a viharban kidől egy terebélyesre nőtt tölgyfa. Ha csakugyan nem érezzük ugyanazt a veszteséget, amikor egy makk tönkremegy, úgy az is igaz, hogy nem érezzük azt a nagy kárt akkor sem, ha egy tölgyfacsemete pusztul el, miközben nyilvánvalóan nem különbözik fajában a kifejlett tölgyfa a tölgy-

72 Michael J. Sandel: Contro la perfezione. L'etica nell'età dell'ingegneria genetica. Milánó, Vita e pensiero, 2014.

73 Uo. 114.; Michael J. Sandel: Embryo Ethics: The Moral Logic of Stem-Cell Research. The New England Journal of Medicine, 351. (2004), 3. 207-209.

74 Uo. 208.

75 Robert P. George: Il diritto naturale nell'età del pluralismo. Róma, Armando, 2006. 167. 
facsemetétől. Ebből látszik, hogy a tölgyfát nem fajtája miatt értékeljük, hanem a kifejlettsége esetén annak impozánssága, fenségessége miatt.

A makk, de a tölgyfacsemete sem lenyügöző megjelenésü, így nem érzünk veszteséget pusztulásukkor - érvel George. Ha a tölgyfák a fajtájuk miatt bírnának értékkel, akkor ebből az következne, hogy ugyanolyan veszteséget éreznénk, ha egy tölgyfa vagy egy tölgyfacsemete megy tönkre. Azonban az alap - folytatja érvelését George -, amely miatt az emberi lények értékét elismerjük, teljességgel más. Ahogy azt Sandel is elismeri, az embereknek éppen sajátos entitásuk miatt tulajdonítunk értéket. Éppen ezért tekintünk minden egyes emberi lényt méltóságban és jogokban egyenlőnek - érvel George. Nem gondoljuk, hogy a különösképpen „nagyszerünek” tekintett emberek - mint mondjuk Michael Jordan vagy Albert Einstein - nagyobb alapvető és immanens értékkel és méltósággal bírnának a fizikailag gyenge vagy a szellemileg visszamaradott emberi személyeknél. Nem türnénk el - írja George - egy szellemileg visszamaradott gyermek vagy egy rákbeteg megölését, hogy szerveik kivételével megmentsék Jordant vagy Einsteint. Nem türjük hasonlóképpen a gyermekek megölését sem, akik Sandel analógiája révén azon facsemetéknek felelnének meg, amelyeknek erdőgondozás keretében való elpusztulásán nem kesergünk, amiképpen azon sem, ha e gondozás keretében makkok pusztulnak el. Az erdőgondozók szabadon vágják ki a tölgyfacsemetéket, és pusztítják el közben a makkokat, hogy ezzel biztosítsák a kifejlett példányok egészségét. Senki nem csinál ebből gondot - jegyzi meg. Éppen azért, mert nincs okunk arra, hogy különösebb értéket tulajdonítsunk a tölgy faj egyedeinek - éppen ellentétes módon azzal, ahogy az az emberi nem (faj) tagjai esetében történik.

Összefoglalva: ha magának a tölgy fajnak tulajdonítanánk értéket, nem pedig a tölgyfa pompázatosságának, akkor ugyanannyira éreznénk kárnak a tölgyfacsemeték és a makkok elpusztulását, mint a kifejlett nagyszerü, pompás tölgyfa tönkremenetelét, kidőlését. Csak gondolati kísérletként: ha oly módon tulajdonítanánk értéket - írja - az embereknek, mint az a tölgyek esetében történik, akkor semmilyen okunk nem lenne arra, hogy ellenezzük a gyermekek vagy akár a súlyosan „fogyatékos" felnőttek megölését. Az emberi embriók megölésének a makk és az emberi embrió között vont analógia alapján való igazolása azonnal létjogosultságát veszti - vonja le a konklúziót George -, ha belegondolunk abba a hatalmas különbségbe, hogy mi alapján tekintjük értékesnek a tölgyet, s mi miatt tulajdonítunk emberi lényeknek belső értéket és méltóságot. A tölgyfát járulékos tulajdonsága miatt tekintjük értékesnek, amely annak eszközértéket biztosít, amíg az emberi lények önmagukban vett értékét ismerjük el, saját emberi entitásukból fakadó immanens méltóságuk okán. ${ }^{76}$

A dolgok, létezők lényegét és azok közötti különbségeket és azonosságokat megragadó álláspont nyilvánvalóan George érvelésében van jelen, aki tud különbséget tenni lényegi elem és járulékos ismérv között. Éppen ebben áll a jogfilozófiai gondolkodás sajátja: az azonosat azonosan, a különbözőt pedig a létező különbözőség mértéke sze- 
rint kell különbözően kezelni ahhoz, hogy igazságosan ítéljünk. Ehhez viszont meg kell tudni ragadni azt az elemit, ami a lényeget alkotja a dolgokban és a létezőkben, s ami nem járulékos, esetleges elem. A kinézet, a fejlettségi szint és a kor csupán járulékos elemek az emberben, minthogy az ember biológiai létrejövetelével jelen van az emberi személy a fogantatásától kezdve. Ez a lényegi elem, a személy mivolt adja minden emberi lény feltétlen és egyenlő méltóságát embrionális korától kezdve a haláláig függetlenül mindenféle járulékos tulajdonságának meglététől, kifejlettségétől vagy éppen annak hiányától, illetve visszafejlődésétől az öregkorában. A kérdés az, hogy mi adja az emberi személylét lényegét, az emberi méltóság voltaképpeni alapját.

\section{A minden emberi személy méltóságát adó lényegi tartalom, a személyes szellemi lelkük felé}

A jogfilozófiai természetű kérdés az, hogy mi adja az emberi személylét lényegét, az emberi méltóság jogi értelemben vett voltaképpeni normatív alapját. Kérdés továbbá az, hogy a jog művelői megelégedhetnek-e továbbra is azzal, hogy a méltóság fogalmának normatív jellegét állítsák, de ne lépjenek egyszersmind e fogalom normativitásának alapja, azaz annak tartalma felé eggyel tovább, azt kutatván, hogy milyen humán valóság adja az ember, minden ember személyi méltóságát. Nézetünk szerint ez ma már nem kerülhető meg, tekintve, hogy az emberi méltóság, de az emberi élet fogalma is - amiként egyébként a személy fogalma is - végletesen relativizálódott, normatív disztinktív tartalmában teljességgel elgyengült. A méltóság napjainkra a radikálisan relativista módon meghatározott önrendelkezési joggal azonosult szemantikailag. ${ }^{77}$ Ennek következtében az az ember ontológiai alapjától teljességgel eloldódott, aminek eredményeképpen már nem adható kielégítő válasz - e koncepcióban - arra az utilitarista kérdésre, hogy miért kizárólag az ember bírna a méltóság lényegi ismérvével, s miért ne rendelkeznének vele a legfejlettebb emlősállatok is. Ha ezt valaki mégis elfogadná, akkor ezzel természetesen el is jelentéktelenítené az ember és a legértelmesebb emlősállatok közötti ontológiai különbséget. A poszthumanista „emancipatorikus” álláspont képviselői pedig már a nagyon fejlett mesterséges intelligenciával rendelkező robotok alanyiságából (gondolkodási, „fájdalomérzékelési” képesség, szerzői alkotásra való képesség, vétőképesség stb.) fakadó „méltóságának” kimondásáért és az azokból fakadó instanciák érvényesítéséért szállnak síkra. Ennek következménye nem lehet más, mint hogy az ember immáron lényegileg nem különbözne jogilag, azaz jogaiban sem a humanoid (emberinek látszó) tulajdonságokkal felruházott, fejlett mesterséges intelligenciával rendelkező robotoktól. E ponttól kezdve értelmesen, azaz megalapozottan nem is lehet az emberi személyiségről mint a természetes emberi személy lényegadó ismérvéről beszélni. Az emancipatorikusnak

77 A helyes szemléletű legújabb jog- és politikai filozófiai irodalomból ld. Claudia Navarini (szerk.): Autonomia e autodeterminazione. Profili etici, bioetici e giuridici. Róma, Editori Riuniti University Press, 2011; Miguel Ayuso (szerk.): La autodeterminación: problemas jurídicos y políticos. Madrid, Marcial Pons Ediciones Jurídicas y Sociales, 2020. 
szánt új fogalomhasználat (robotok mint „érző, gondolkodó lények”, emberek mint „emberi állatok”, s az állatok mint „nem emberi állatok”) nyilvánvalóan nem követi le ezek után a dolgok, azaz az állatok, az emberi személyek és a fejlett mesterséges intelligenciával rendelkező robotok természetének lényegei különbségeit. A fogalmakat, a jelentéseket oly módon szükséges tehát alakítani, hogy azok szemantikai tartalma lefedje a dolgok lényegét.

A fentiek miatt nézetünk szerint az emberi méltóság (erősebb) tartalmi, azaz teoretikus filozófiai megalapozására van szükség, amelynek jogfilozófiai konzekvenciái a tételes jogtudományok szinte majd mindegyik területén alkalmazandók. A méltóság normatív fogalmának puszta kijelentése ugyanis a különböző méltóságkoncepciók egymást átfedő tartalmú egybeesése, továbbá annak immáron bármiféle tartalmi megalapozása híján már nem képes minden ember életének egyenlő és megfelelő szintű jogi, szilárd normatív (kötelezően érvényesítendő) védelmét biztosítani.

A jog számára az ember helyes koncepcióját a természetjogias beállítottságú jogfilozófiai gondolkodás képes szolgáltatni, amely a maga részéről a filozófiai antropológia eszköztárára támaszkodik. A valóban helyes morálteológiai és filozófiai antropológiai alapokon álló természetjogi gondolkodásmód a katolikus keresztény. ${ }^{78}$ Azonban bármilyen helyes filozófiai antropológia a méhmagzat feltétlen méltóságát csakis személy voltával tudja megalapozni, amely a szellemi lélek benne való megléte révén adott: az emberi embrió emberi individuum, egyedi létező, akinek feltétlen méltóságát csakis a lelke adhatja, amely biológiai létének első pillanatától kezdve jelen van benne. Az alapvető emberi jogok azért illetik meg az embereket, mert méltósággal rendelkező személyek, mégpedig azért, mert a fogantatásuktól kezdve lelkük van. Az emberi természetnek van egy biológiai és egy szellemi természetü lelki ${ }^{79}$ oldala (továbbá pszichés is): a megtermékenyülés révén létrejön az egyedi genetikai prog-

78 Luther Mártonnál a jog és a természetjog sem kap valódi szerepet az Istenhez vezető út tekintetében, vagyis a végső cél elérésében. Innét ered a protestantizmusnak tulajdonított jogellenesség, amely korunkban már határozottan oldódni látszik, de ami mint végső értékelésben megállapítható természetjog-ellenesség továbbra is fennáll. Francesco D’Agostino: Il Diritto come problema teologico. Torino, G. Giappichelli, 1995. 18. Különösen így van ez, ha a természetjog katolikus gondolati irányzatban betöltött szerepével vetjük össze a természetjog protestáns koncepcióit. A nem egyszer megfogalmazott protestáns jog- és természetjog-ellenesség végeredményben azt jelenti, hogy a jog tartalmát (protestáns) teológiai értelemben nem a természetes erkölcsi törvény, hanem magának Istennek a parancsolatai adják. Itt gondolhatunk A. Lang, Ernst Troeltsch vagy akár Francesco D’Agostino azon véleményére, hogy eredetileg is a reformáció neves képviselőinek teológiájában és társadalomtanában, más korok természetitörvény-tanaival összevetve, a természeti törvény tárgymeghatározásaival és egyáltalán pozícióját tekintve valamelyest visszafogottabban szerepel, de vannak olyanok is, akik ennél radikálisabban fogalmaznak.

79 A „lelki” dimenzió alatt az emberi személy azon halhatatlan szellemi dimenzióját értjük, amely az istenképüség leglényegibb sajátja, s amelynek érzékszerve az erkölcsi cselekvésre képes emberi személynél a lelkiismeret: „A szellemi lélek nem a szülőktől származik, hanem közvetlenül Isten teremti és halhatatlan. Amikor a halál pillanatában elszakad a testtől, nem vész el; újra egyesülni fog a testtel a végső föltámadás pillanatában." A Katolikus Egyház Katekizmusának Kompendiuma, 70. pont. Ez adja minden ember méltóságát, és biztosítja az emberek lényegi egyenlőségét (412. pont). A lélek halhatatlan, s a konkrét emberi személy lelke erkölcsi tettei alapján kerül majd megítélésre (205. pont). Az emberi lélek Istentől származik, és isteni természete szerint Őfelé tart, amely 
rammal rendelkező új emberi lény, aki így biológiai értelemben a Homo sapiens faj új egyede, természetének leglényegibb része azonban a személyes lelke.

Természetesen nem létezik a személy a megtermékenyülés előtt, mindazonáltal az új egyén genetikai programjánál több az emberi természet, amely az emberi személyjellegben nyeri lényegi tartalmát, s ami az adott emberi személy lelke, s ez az új emberi lényben jelen van a fogantatása pillanatától kezdve. Az ember nem azért rendelkezik alapvető emberi jogokkal, köztük a méltóságának és életének védelméhez valókkal, mert a Homo sapiens fajhoz tartozik, hanem mert személyes lélekkel rendelkező emberi személy teljesen egyedi emberi testben a fogantatásától kezdve. A személy léte az ember léte: az egyedi emberi élet biológiai létének keletkezése időpontjában kezdődik, azaz a fogantatással, és létének megszűntéig tart, amelynek megállapítása jóval összetettebb kérdés, mint azt eddig gondolták. Az ember halálának valósága meghaladja a biológiai halál tényszerűségének dimenzióját, amely végérvényes bekövetkezésének s így visszafordíthatatlanságának meghatározása egyébként az orvostudomány dolga és felelőssége.

Úgy tűnik azonban, hogy ez utóbbi egyáltalán nem redukálható az agyhalálra, minthogy az inkább csak a halál bekövetkezésének statisztikai (kvantifikálható) jelenségeken alapuló prognózisa, semmint az egyedi esetben bizonyossággal megállapítható diagnózisa. Megjegyzendő, hogy a halál agyhalálként történő problémátlan meghatározása körül, amelyet korábban megfellebbezhetetlen biológiai tényként kezeltek a közbeszédben, az elmúlt években számos orvostudományi, biológiai, bioetikai s filozófiai természetű kérdőjel támadt. Mivel a halál mikénti megállapításának komoly emberi jogi vonzata van, ezért annak egynémely jogfilozófiai természetű kérdésére az utolsó fejezetben még visszatérünk.

Általános érvénnyel kimondható, hogy a személy mivolt nem az emberi biológiai lét vagy emberi élet egyik minősített állapota, jellemzője, hanem teljesen azonos magával az emberi léttel. ${ }^{80} E$ lét emberspecifikus minőségét az emberben levő szellemi lelke adja, ami ezért mind az ember létrejöttének (fogantatás), mind halálának kulcstényezője. Bár hajlamosak vagyunk a felnőtt emberben észlelni elsődlegesen a kiteljesedett személyiség szellemi létének ismérveit és az azokon keresztül megnyilvánuló emberi méltóságát (a jog is a felnőtteket védte történetileg elsőként az embertelen és megalázó, vagyis az emberi létmóddal ellentétes büntetési nemekkel szemben), mégis azt kell, hogy mondjuk, minden ember emberi jogai mindvégig emberi személyi természetükből fakadnak, és azok így jelen vannak a természetes létezésük pillanatától kezdve egészen addig, ameddig testükben élnek. ${ }^{81}$

folyamatot az erkölcsi erények segítik, a bűn viszont - mert gyengíti a helyes szeretetet - gátolja: (396. pont). A „pszichés” dimenzió pedig az, amelyet a - helyes szemléletű - pszichológia vizsgál.

80 Vö. Spaemann (2005) i. m. (66. lj.) 241.

81 „Ez a méltóság az ember jellemében gyökerezik. Egy személy függetlensége azonban mégis azon múlik, hogy ne illessen meg senkit az ítélkezés joga, hogy egy másik ember rendelkezik-e, vagy sem a személyiség (Personalität) alapvető jegyeivel. Emberi jogok függnek attól, hogy senki se legyen illetékes meghatározni azok körét, akiket megillet vagy nem illet meg a személyiség joga. Ez azt jelenti, hogy ezeket a jogokat, noha az ember egyéniségén alapszanak, mégis minden emberi lény 
A jogtörténet fejlődését tekintve elmondható, hogy az emberi test jogi védelme az ember méltóságának védelmére irányult, minthogy e test jogsérelme a méltóság sérelmét valósítja meg. A jog a testen keresztül az ember méltóságának védelmével tulajdonképpen az ember szellemi dimenzióját, lelkét védi, ami a humánum lényegi dimenziója. A megalázó testi büntetések és a kínzás vagy az embertelen bánásmód alapvető emberi jogok érvényesítésén nyugvó tilalmának alapja is ezen a koncepción nyugszik, még ha nem is mindig reflektáltan. ${ }^{82}$ Ezzel összefüggő érdekes tény, hogy a civilizált emberiség mindig is valamiképpen lenézte a hóhér szakmáját, minthogy annak gyakorlását az emberi méltósággal kevéssé összeegyeztethetőnek tartotta, miközben akit kivégeztek, annak különleges alkalma volt arra, hogy demonstrálja méltóságát a kivégzésekor, tiszteletet váltva ki ezáltal a kivégzés nézőiből..$^{83}$ Általános érvénnyel kijelenthető, hogy egyrészt az ember természetében rejlő immanens erkölcsi méltóságát a megalázó bánásmód sem képes meggyalázni, mert az hozzáférhetetlen külső eszközök által, másrészt az is, hogy annak külső sértését jogi eszközökkel is feltétlenül tiltani kell, ${ }^{84} \mathrm{~s}$ különösen azt, hogy azt maga a jog próbálja eszközeivel sérteni.

A méltóság természetét tekintve annyira „sérthetetlen”, immanens az emberben, hogy azt senki sem veheti el az embertől, legfeljebb adott esetben azt a konkrét egyén nem tiszteli a másikban, s ilyen értelemben azt megsérti benne, mindazonáltal mégsem foszthat meg senkit sem a méltóságától. ${ }^{85}$ Így kell tekintenünk a méhmagzati stádiumú emberi személyre is, s ily módon kell vele bánnunk. Az emberi méltóság meglétének nem biológiaiak az „okai”, hanem annak következtében vagy annak révén rendelkezünk méltósággal, hogy biológiailag a szabad szellemi lények családjába tartozunk. ${ }^{86}$ Aki megsérti a másik méltóságát, az egyszersmind magában is megsérti azt, $\mathrm{s}$ aki ezt súlyosan és rendszerint teszi meg, az lassanként elembertelenedik vagy „elállatiasodik", mert mivel emberi személyekként egy és ugyanazon emberi nemhez tartozunk, ezért a lényegünket adó méltóság is közös bennünk. Ily módon a méltóság súlyos és tömeges megsértése az egész emberiség, az emberi nem lényegét adó „emberiesség" elleni bün a mi felfogásunkban, bárki is legyen az emberi nemben a jogsértés tárgyként kezelt alanya: méhmagzati életstádiumú személyek (abortusz), öntudatlan haldokló emberek (eutanázia) vagy egész („faji”) népcsoportok tagjai, akiket ellenségeik ki akarnak irtani (népirtás). Mivel az ember nehezen képes önmaga számára megindokolni, hogy emberi lényege, azaz saját „emberiessége” s az abból fakadó erkölcsi, racionális és affektív instanciák ellen követ el bünt, ezért eufemisztikus meg-

számára el kell ismernünk, mégpedig természetes létezése első pillanatától kezdve, anélkül hogy bármiféle pótlólagos tartalmú kritériumot szabhatnánk." Robert Spaemann: Az emberi természet fogalmáról. In Krzysztof Michalski (szerk.): A modern tudományok emberképe. Budapest, Gondolat, 1988. 147-148.

82 Vö. Stefano Rodotà: La vita e le regole. Tra diritto e non diritto. Milánó, Feltrinelli, 2009. 74.

83 Spaemann (2018) i. m. (5. lj.) 35.

84 Uo. 34

85 Uo. 36.

86 Uo. 34 . 
nevezéseket talál ki tetteire: „jó” vagy „kegyes” halál, „terhességmegszakítás”, szexuális reprodukciós önrendelkezési jogok gyakorlása a saját női teste felett stb.

Az ember létrejöttének bioetikai szempontú megközelítéséből az mondható el, hogy az emberi test az egysejtű zigótastádiumától kezdve emberi szervezet, azaz az emberi fajba tartozó élőlény, egyedülálló, integrált és szervezett saját organizmussal, amely magában foglalja és tartalmazza az összes egyedi és specifikus genetikai információt, amelyek teleológiai és autonóm módon a test teljességében való megvalósulása felé tartanak a folyamatos, fokozatos és koordinált fejlődés különböző fázisain keresztül. Szakadatlan fejlődésről, fokozatos komplexifikációról beszélhetünk, a test kiformálódásának irányába tartó rendezett és célirányos szabályosságról, tehát semmiképpen sem esetleges véletlenszerüségről vagy okozatos sorozatszerüségről. ${ }^{87}$ Márpedig, ha a fejlődés folyamatos, akkor - állítják meghatározó, katolikus, bioetikával foglalkozó jogfilozófusok - az emberi embrió bioetikai értelemben is már személy, amennyiben bár még nem aktualizálódott és teljesedett ki minden sajátossága, már jelen vannak azon feltételek, amelyek a szükséges támogatást adják azon szakadatlan dinamikus folyamat számára, amely lehetővé teszi ezen ismérvek realizálódását. ${ }^{88}$

Szigorúan bioetikai megközelítésből nézetünk szerint csak az mondható ki - ami egyébként önmagában is nagy jelentőségű dolog -, hogy az emberi embrió biológiai értelemben emberi lény. Azt azonban, hogy az emberi embrió szellemi lélekkel bíró személy, s ezért jogalany, azt az erkölcsteológián, valamint a filozófiai antropológián kívül a morál- és a jogfilozófia (természetjog) állapíthatja meg, amelynek képviselőinek egyszersmind ki is kell jelenteniük ezt, ha konzekvensen az ember lényegének meghatározására koncentrálnak elemzéseikben. E diszciplínáknak nélkülözhetetlen a hozzájárulása a jogi emberi életvédelem területén, hiszen az emberi méltóság - nézetünk szerint - csakis a szellemi lélekkel alapozható meg. Az orvostudomány és a bioetika tudományai a lélekkel bíró ember személyi méltóságát úgy képesek indirekt s más diszciplínák által nem pótolható módon védeni az emberi embrióban és magzatban, hogy a lényegi biológiai azonosságot mutatják ki az emberben annak minden biológiai életstádiumában. Az ember életének és méltóságának jogi védelme megalapozásához az elsődleges, direkt és meghatározó megközelítési mód számunkra tehát a tág értelemben vett, természetjogi alapú jogfilozófiai megközelítés, amely az emberben a szellemi lelket nevezi meg azon ismérvnek, amely lényegi, tehát ami minden emberben jelen van, s amely az emberi személy méltóságát, annak alapját adja annak fogantatásától kezdve.

Posztmodernnek nevezett korunkban a méltóság immáron üres fogalommá vált, azzá kellett szükségszerűen válnia, mert e doktriner (bizonyítatlan) alapelveket

87 Francesco D’Agostino - Laura Palazzani: Bioetica. Nozioni fondamentali. Brescia, La Scuola, 2016. 80 .

88 Uo. 81. A szerzőpáros egyértelműen kijelenti - helyesen -, hogy az emberi embrió már emberi személy, ami az immanens méltóságát erős értelemben megalapozza és igazolja. Az embrió emberi személyi jellege alapozza meg jogalanyiságát, azt tehát, hogy jogai vannak (Uo. 82.). Ezt azonban inkább mint jogfilozófusok jelenthetik ki, s nem annyira mint bioetikával foglalkozó tudósok. 
tartalmazó voltaképpeni ideológia tagadja a dolgok s különösen az ember lényegi természetének létét, annak vizsgálhatóságát, márpedig a méltóság éppen ezt a célt töltötte be nem sokkal ez előttig a jogi és a filozófiai gondolkodásban egyaránt. A filozófiailag korrekt, következetes teoretikus állásfoglalás nézetünk szerint az, ha a dolgokat a maguk valójában tekintjük a természetjogi (ontológiai) realizmus bázisán, s kimondjuk, hogy az embert szellemi lelke teszi azzá, ami, s e méltóságának alapját adó lényegi ismérve egyszersmind meg is különbözteti őt az állattól, még a legfejlettebb emlősöktől is.

Az emberre vonatkozó géntechnológia körüli morál- és jogfilozófiai viták csak megújították és új dimenzióba helyezték azon szemlélet érvkészletét, amelyet az abortusz, az eutanázia, a súlyosan fogyatékkal élők, valamint a csecsemők jogai kapcsán már régóta használnak. Ennek lényege abban áll, hogy csak azon, a legalapvetőbb képességei birtokában levő felnőtt minősül emberi személynek, aki racionális és autonóm, vagyis aki maga képes erkölcsi döntést hozni, mégpedig jobbára a fenti értelemben, vagyis aki önmaga képes az értékeket a maga számára meghatározni. Akik erre nem képesek, mivel az alapvető képességeik híján vannak, vagy azért, mert azok még nem fejlődtek ki (magzatkorú emberi személy), vagy pedig, mert azokat jelenleg nem gyakorolják szerintük (stabilan vegetatív kómában levő személy), vagy már megszűntek azokat gyakorolni (minthogy a halálhoz közeli állapotban megszűntek annak gyakorlásához szükséges élettani funkciók), vagy mert soha nem is alakultak ki azok (nagyon súlyos agyi károsodással élő személy esetében), azok nem emberi személyek. Ezeket - esetektől függően - csak leendő vagy potenciális személyeknek, vagy éppen csak emberi testnek tekintik emberi személy mivolt nélkül. Ezeknek lehet bizonyos értelemben vett emberi élete, minthogy emberi testük él, viszont mivel az emberi személyi létezés legfontosabb képességeivel, amelyek az autonóm önmeghatározáshoz szükségesek, még nem, már nem, vagy éppen sohasem rendelkeztek, ezért megfosztják e személyeket e mivoltuktól, és így méltóságuktól.

Figyelembe veendő („kritikus”) érdekük ugyan lehet, de azokkal szemben elsőbbséget élveznek az élő - egészséges felnőtt - emberi személyek érdekei, alapvető jogai. John Finnis egy többmenetes vitát folytatott az eutanázia kérdésében egy neves, a liberális álláspontot fémjelző filozófussal, amely érvelés tekintetében kiütközött ugyan a neoklasszikus természetjogi érvelés minden gyengéje s elégtelensége ${ }^{89}$ mindazonáltal abban teljes mértékben igaza van Finnisnek, hogy Harris érvelésében kimutathatóan vannak olyan kategóriájú személyek, akiknek az állapotuk folytán „meg kell halniuk".90 Nem teljesen ok nélkül hivatkozik arra folyton Harris, hogy a látszat ellenére sokkal több Finnisszel a közös pont, mint a különbözőség, ami ellen egyébként Finnis a vita vehemenciájából és stílusából kitűnően tiltakozni igyekszik. Finnis a vitát az említett ténnyel igyekszik lezárni és dűlőre vinni. Azonban nézetünk szerint ő is

89 Vö. Frivaldszky (2019) i. m. (9. lj.) 182-188.

90 John Finnis: Misunderstanding the Case against Euthanasia: Response to Harris's First Reply. In John Keown (szerk.): Euthanasia Examined: Ethical, Clinical and Legal Perspectives. Cambridge, Cambridge University Press, 1999. 62., 65., 67. 
foglya marad a képességek gyakorlásának kritériumát középpontba állító gondolkodási módnak - s erre rámutat Harris is -, minthogy Finnis érveléséből az tünik ki, hogy az emberi személyi lét végül is bizonyos „radikális” emberi képesség gyakorlásához kötött, még ha ezt Finnis végül is minden élő emberi személynél feltételezi is.

Öszintén szólva nehéz megérteni, hogy miként rendelkezik e képességekkel egy évek óta kómában levő személy, miközben mind ö, mind mi természetesen minden más emberi személlyel egyenlő méltósággal rendelkező emberi személynek tekintjük őt. Finnis érvelésének irányultságáról egyébként elmondható, hogy az emberi élet védelmének kezdetét - természetjogi szempontból - helyes módon köti az emberi személy biológiai életéhez, s helyesek a törekvései az eutanázia legalapvetőbb emberi értékeket sértő, sőt támadó jelenségének kritikájában, amelyet olykor már-már vehemens módon tesz meg, ami nyilvánvalóan a veszélyeztetett jogtárgy (emberi élet) legfőbb értékének szándékával magyarázható. (Gyengíti viszont érvelésének erejét az, hogy az emberi élet mint alapvető emberi jó tézise szerint összemérhetetlen más alapvető emberi javakkal. Nézetünk szerint az emberi élet összemérhető a többi emberi jóval, értékkel, s azok hierarchiájában a legmagasabb helyet foglalja el az emberi természet rendje szerint.)

Mi azonban nem bizonyos legalapvetőbb képességek megléte vagy potenciális gyakorlása miatt tekintünk minden élő embert abszolút méltósággal rendelkező személynek, hanem mert minden embernek teljesen egyedi, szellemi természetű emberi lelke van. Még csak nem is az alapvető emberi értékekre irányuló képességek gyakorlása, hanem az emberi életének megléte teszi ôt személlyé, mivel minden élő ember emberi lélekkel rendelkezik. A humanitása és méltósága objektív, mivel azok az emberi életével eleve adottak. Nem az emberi fajhoz (Homo sapiens) való biológiai tartozásból kellene a méltóságot levezetni - mint korábban már utaltunk rá -, hiszen az emberi természet már akárcsak ilyen módon is számba vett leglényegibb tulajdonságai sem magyarázhatók voltaképpen sem genetikai, sem társadalmi okokkal, miközben azok objektíve léteznek.

Mindezt Francis Fukuyama Poszthumán jövendönk címü nagy hatású könyve kapcsán kell megállapítanunk. ${ }^{91}$ Számos alapvető tulajdonságát sorolja fel az embernek mint erkölcsi, társas és politikai lénynek, azonban az emberi lelket nem említi. Sajnos - de talán nem is annyira meglepő módon - azonban Finnis sem erre építi fel tanulmányait, amikor az eutanázia ellen érvel. A helyes irányt a tradicionális tamásitomista természetjogi tanok képviselői követik, amelyet mi is a három legalapvetőbb emberi jog (az élethez, a méltóság és a jogalanyiság elismeréséhez való jogok) legjobb megalapozási módjának tartunk azzal kiegészítve, hogy a keresztény filozófiai perszonalizmussal ellentétben nem az ember erkölcsi-társas-társadalmi kiteljesedését tekintjük elsődlegesnek az emberi személyben, hanem magát az e kiteljesedést igénylő szellemi lélek meglétét, ami egyébként így azoknak előfeltétele is egyben.

91 Francis Fukuyama: Poszthumán jövendőnk. A biotechnológiai forradalom következményei. Budapest, Európa, 2003. 
Finnis azonban az elméleti alapállásának megfelelően ${ }^{92}$ nem kívánja a metafizikai módon tekintett emberi természetből, az ily módon teoretikusan megfogalmazott emberi lényeg alapján megfogalmazni az emberi személy humanitását, emberi méltóságát, s ezekből közvetlenül kibontani az ember méltóságának és életének elismeréséhez és védelméhez való jogát. Márpedig az objektív erkölcsi rend melletti döntés (amelyet a „lelki-ismeret” vezérel), illetve az ember életének értelmére való rákérdezés képessége, de az erkölcsi érzelmek is az emberi lélek működésének kifejeződései, különböző, de mégis egy irányba mutató megnyilvánulásai. Az ember szellemi lelkének működése természetesen empirikus eszközökkel nem igazolható, azonban az ember „szellemi dimenziója”, ahogy azt a logoterápia megalapítója, Viktor Frankl nevezi, bizonyíthatóan létezik, ${ }^{93} \mathrm{~s}$ müködésében tetten érhetö, ráadásul az - önmagában véve - nem is képes megbetegedni. ${ }^{94}$ A szellemi lélek természetesen azon személyekben is jelen van (magzatok, csecsemők, súlyos agykárosodottak, demensek, kómában levők stb.), akik esetében annak működése külső cselekvésekben megragadható módon nem realizálódik, nem nyilvánul meg. A lélek jelenléte, működése - mint ismeretes - nem is a külső cselekvésekben érhető tetten elsősorban.

Spaemann érvelése meggyőzőnek tünik, s bizonyos fokig hatásos is tud lenni azon esetekben, amikor a hétköznapi intuitív gondolkodás igazságából merít néhány főbb érvet arra, hogy miért tilos az ember klónozása, in vitro megtermékenyítéssel való létrehozása, de genetikai manipulálása is. ${ }^{95} \mathrm{Az}$ emberek létrejöttének egyenlőségét jelenti az, hogy mindenkit a természet hozott létre, s senkit sem ember akart „legyártani”. Az ember egyszerüen nem vállalhatja a felelősséget senkinek sem létéért vagy nemlétéért. Ez utóbbiból lehet az emberölés tilalmát levezetni - írja. Az előbbi alapján pedig a gyermek szülők felé irányuló azon kérdésére, hogy miért akarták őt létrehozni, azt mondhatják, hogy te ugyanúgy jöttél a világra gyermekem, mint bármely más ember, a szeretetkapcsolatunk révén, vagyis a természet révén - írja Spaemann. Nagyon fontos momentum lehet a gyermek számára az, hogy a szüleinek szeretetkapcsolatából jött létre, azaz szeretetből. Továbbá az, hogy ő személy szerint nem emberi akarat terméke, hanem szülei szeretetéből születő, de mégis a maga konkrét individuális formájában, előre nem látott, tehát így konkrétan nem ismert emberi személy, azaz ajándék, s egyfajta misztérium a léte. A keresztény tanítás alapján azonban még hozzátehetjük: valaki viszont konkrétan őt akarta, hogy megszülessen, s hogy élete legyen, s ez az a Teremtő, aki szeretetből hívta őt életre, és egészen konkrét szeretet-

92 Frivaldszky (2019) i. m. (9. lj.) i. m. 182-188.

93 Viktor Frankl tételszerüen kijelenti, hogy a „személy szellemi” lény. Viktor E. Frankl: Értelem és egzisztencia. Előadások és tanulmányok. Budapest, Jel, 2006. 60. A szellemi a személyben a specifikusan emberi dimenzió. Stephen J. Costello: Logotherapy as Philosophical Practice. In Sárkány Péter - Vik János (szerk.): Logoterápia és egzisztenciaanalizis, 7. (2015), 3. 137.

94 „A valóságban ugyanis egyáltalán nincsenek »szellemileg« betegek. Mert a »szellem«, maga a szellemi személy, egyáltalán nem betegedhet meg." Frankl i. m. (93. lj.) 61. Vö. Stephen J. Costello: The Spirit of Logotherapy. Religions, 7. (2016), 3. 6.

95 Robert Spaemann: Christianity and Western Philosophy. In Silja Vöneky - Rüdiger Wolfrum (szerk.): Human Dignity and Human Cloning. Leiden-Boston, Martinus Nijhoff, 2004. 47-51. 
terve van róla. Ez a tudat, hogy szeretetből jött létre, s hogy léte nem emberi produktum, s nem emberi akarat terméke (s különösen, hogy nem „életre erőszakolták” őt in vitro megtermékenyítéssel), fontos lehet a számára, különösen az élet nehéz pillanataiban, amikor esetleg életének értelme kérdőjeleződik meg, akár az öngyilkosságot is fontolgatva.

Spaemann érve nagyon hatásos a tekintetben is, hogy a hétköznapi helyes ráérzés alapján nagyon helyesen mondja azt az anya a gyermekének, hogy „amikor terhes voltam veled...," ${ }^{96}$ hiszen ekkor nem egy általános vagy személytelen alanyra gondol, hanem egy egészen konkrét személyre, jelen esetben reám, aki „én” voltam már akkor is individuális, egyedi mivoltomban az ő „hasában”. Az Alkotmánybíróságunk többségi véleménye már ezért is a helyes hétköznapi intuícióval ellentétes volt, amikor nem ismerte el a magzatkorú emberi személy személy-, azaz jogalany voltát. A jogásznak azt kell érzékelnie, hogy a hétköznapi morális intuíció helyes-e a dolog természete alapján. Amelyik esetben helyes, ott az érvelésben lehet rá támaszkodni, ahol viszont helytelen, ott a helyes természetjogi gondolkodási utat kell követnie az érvelésében.

Fontos e tekintetben, hogy a biológiai fejlettségük vagy a biológiai állapotuk miatt leggyengébb helyzetben levő emberi személyek esetében ne abból induljunk ki, hogy mi milyennek látjuk kívülről, vagy képességeik révén mennyit tudnak megvalósítani a felnőttekéből vagy az egészségesekéből, illetve hogy milyen az ilyen emberi személyekhez való viszonyunk. Az ő egyenlő és feltétlen emberi méltóságuk megléte ugyanis nem annak mások általi percepciójától függ, de nem is attól, hogy mennyire érezzük, éljük át az ő emberségüket, például a hozzájuk való kötődés által. Egy néhányhetes magzathoz az emberek többsége nemigen kötődik még (ezért sem szokták őt eltemetni), míg a csecsemőkorú gyermekeikért akár már az életüket is képesek lennének a szüleik, de különösen az anyuka - aki kerülhet ilyen helyzetbe - odaadni. A magzat korú emberi lény, azaz emberi személy morális státusa azonban ettől még nem alacsonyabb - ellentétben Fukuyama állításával - a csecsemőénél vagy a kisgyermekénél.

A csecsemőgyilkosságot nem azért tekintjük mindannyian a lehető legnagyobb bűnnek, mert ezáltal nem jöhet létre belőle felnőttként az „erkölcsi személy”,97 mert akkor a felnőttek megölését nagyobb bủnnek kellene tekintenünk a csecsemőgyilkosságnál. A valós helyzet az, hogy ez utóbbit azért tartjuk a felnőtt megölésénél is borzasztóbbnak, mivel a csecsemőben és a gyermekben mintegy sürítve véljük érzékelni a humanitás, az emberlét értékét, annak ártatlan és tiszta formájában, azaz magát az emberi lélek méltóságát és sérthetetlenségét a kis emberi lényben.

96 Spaemann (2004) i. m. (95. lj.) 48.

97 A kisgyermekeknek - Engelhardt koncepciójában - nincsenek létükkel vele járó jogaik. Mint lehetséges, jövőbeli, azaz majdani reális személyekként lehet morálisan igazolt a jogi védelmük. H. Tristram Engelhardt: Manuale di bioetica. Milánó, Il Saggiatore, 1999. 169. Szerinte az emberi és a nem emberi állatok megvédése az értelmetlen kínzástól, akik nem személyek, a jótékonykodásra (jótéteményre) vonatkozik. Ebből kiérezhető e magatartás nagyvonalúan tanúsítható, azaz opcionális, nem kötelező jellege, valamint az, hogy ha ezt a magatartást tanúsítják, az az erkölcsi cselekvő (felnőtt) személy morális érdeme lesz. 


\section{A szellemi lélek mindenkiben és mindenkor való megléte adja az ember lényegét és minden ember méltóságát}

Helyes morálfilozófiai és jogfilozófiai szemléletben a szellemi lélek képezi tehát az emberi lét lényegét, s adja az emberi személy feltétlen méltóságának az alapját. E szellemi lélek nem csupán $\mathrm{s}$ nem is elsősorban a racionális-morális belátási, döntési és cselekvési tevékenységben, és még csak nem is az emberi élet értelmére irányuló kérdésfelvetés és az arra való válasz megtalálásának képességében érhető tetten, márpedig az emberben a logoszt hagyományosan így értik. Eddig legfeljebb addig jutottak el a helyes irányban gondolkodók, hogy a méhmagzati és a csecsemőkorban az ember még nem rendelkezik azon agyi, központi idegrendszeri biológiai fejlettséggel, amely a gondolkodás szellemi funkciójának meglétéhez szükséges, azonban már a lelkük ebben a korban is készen áll arra, hogy ezt a funkciót később majd gyakorolja. Amiképpen a zongoraművész ilyenkénti minősége sem változik meg természetesen azáltal, ha éppen nem áll rendelkezésére egy zongora, amelyen e képességét gyakorolhatná vagy bemutathatná, s így aktuálisan „nem tud” zongorázni. ${ }^{98}$

Mi azonban az ember természeti lényegét adó szellemi lélek létét nem abban látjuk, hogy majd képes lesz effektive gyakorolni azon szellemi-gondolkodási funkciókat, amikkel a (racionális) lelke potenciálisan már a méhmagzati stádiumban rendelkezik, csak még biológiai, központi idegrendszeri és egyéb biológiai fejletlenség miatt azok még nem nyilvánulnak meg. Meggyőződésünk szerint ugyanis a lélek a majd kifejlődő vagy éppen sohasem realizálódó gondolkodási funkcióktól mentesen is teljesen jelen van mind a méhmagzati emberben, mind természetesen a csecsemőben, még a központi idegrendszerében, agyi működésében genetikailag legsúlyosabban károsodott emberben is. ${ }^{99}$ Nyilvánvaló, hogy a kifejlődött emberben a lélek a morális ítéletalkotás és gondolkodás számos formájában nyilvánul meg (a lelkiismeret múködésétől a nemes erkölcsi eszmékért való lelkesedés képességéig bezárólag), azonban a szellemi lélek a fogantatás pillanatától való azonnali jelenléte teszi a biológiai értelemben létrejött egyedi embert filozófiai, azaz lényegi, voltaképpeni (tulajdonképpeni vagy „sajátképpeni”) értelemben emberi lénnyé, személlyé. A lélek benne van és marad is az emberi létének, életének legvégéig.

A szellemi lélek nem az elme, ekképpen nem is azonos az agy fiziológiai-neurológiai mủködésével, s nem is lokalizálható oda helyileg, szervileg. A halál éppen ezért nem csupán és nem is elsősorban biológiai fogalom, hanem az ember létével és mibenlétével összefüggő, filozófiai (és főképpen teológiai) módon megragadható való-

98 Spaemann (2018) i. m. (5. lj.) 65.

99 Robert Spaemann nagyon lényeglátóan ekképpen fogalmaz: „Ahelyett, hogy oda jutnánk, hogy ahol már nincsen semmilyen gondolkodási képesség, ott az emberi lény testi formája (forma corporis) eltünik, csakis arra juthatunk, hogy amíg az emberi lény teste nem hal meg, a személyes lélek is jelen marad." Ez utóbbi az egyetlen - írja -, amely a katolikus doktrínával összhangban van, majd hozzáteszi, hogy az egyetlen, amely az európai filozófiai hagyománnyal kompatibilis. Ez utóbbi azért is figyelemre méltó állítás, mert a gondolkodás eszmetörténetének egyik legkiválóbb ismerőjéről van szó. Uo. 67. 
ság. A probléma abban áll, hogy az emberi személy e lényegi voltát adó emberi lélek fogalmát sokan a pro-life beállítottságú érvelésekben is kerülik, nem is szólva más jellegü szemléleti alapállásokról, s ha védeni kívánják a magzat életének értékét, akkor valamilyen más minőséggel kívánják a valamiképpen emberinek tekinthető méltóságot abban megalapozni, jobbára azzal, hogy a magzat is az emberi faj tagja. Csakhogy egy biológiai adottság, a faj(ta)jelleg nem alapozhat meg transzcendens, azaz metafizikai minőséget, amilyen pedig a szellemi lélek az emberben. ${ }^{100}$

A legújabb morál- és jogfilozófiai gondolkodási tendenciák eredményeképpen sajnos az emberi lélek, a méltóság és a személyiség fogalmai immáron delegitimálódtak a tudományos diskurzusban. Előbb metafizikai alapjuktól elszakítván kiüresíttettek, majd ennek következtében tartalmilag értelmezhetetlenné, s ezért feleslegessé váltak az emberről és így az emberi jogokról való elméletalkotásokban. Az emberi személy mibenlétének jogi diskurzusokban való teoretikus meghatározása alól mintegy kiszaladt a talaj, minthogy a jogi fogalomhasználatokat alapvetően befolyásoló jogés morálfilozófiai, illetve esetleg politikai filozófiai érvelésekben is végzetesen problematikussá vált az emberi személy létének mibenléte. Terminológiai innovációkkal, avagy szemléleti módosítások eredményezte újabb emberredukcionizmusokkal (például az agyhalál koncepciója) e filozófiai probléma - amely leginkább gondolkodásbeli mélypontként azonosítható - immáron nem oldható meg vagy orvosolható, sőt ezek inkább összezavarták a hajdanvolt tisztánlátást.

Pár évtizeddel ezelőttig ugyanis mindenki számára világos volt, hogy mi az emberi személy, s hogy annak a lelke valahol a „szívében van”, s hogy a szellemi dimenziója áthatja értelmét és gondolkodásmódját is. Ezzel szemben manapság mind a személy, mind a lélek fogalmát kerülik a tudományos érvelésekben, sokszor még az életvédő okfejtésekben is, amikor az emberi jelleget kívánják hangsúlyozni a méhmagzat esetében. Ezért marad az „emberi jelleg” nyomatékosítása vagy pusztán az (emberi) élet védelme szükségességének hangoztatása e méhmagzati stádiumban. Csakhogy az érvelésekben olykor még tetten érhető „méltóság”, amely az emberi fajhoz való tartozásból fakadna, hasonlóképpen filozófiailag nem jól meghatározott fogalom, mint amilyen szerintük a személy fogalma is. Egyébként is Peter Singernek igaza lenne ekképpen: miért lenne egy biológiai fajnak, a Homo sapiensnek méltósága, $\mathrm{s}$ a többi fejlett emlősnek pedig nem (amelyek pedig a fájdalomérzékelésük miatt hasonlóképpen képesek szenvedni), hiszen ez „faji diszkriminációt” valósít meg? ${ }^{101}$

A helyes megközelítés ezzel szemben az - mint már utaltunk rá -, hogy az emberi embrió és a magzat azért rendelkeznek emberi méltósággal, mert emberi személyek, mégpedig azáltal, hogy a személyeknek a fogantatásuktól kezdve szellemi lelkük

100 Vö. Navratyil i. m. (67. lj.) 264., 266.

101 Peter Singer sérelmezve állapítja meg, hogy az újszülött élethez való jogát az alapozza meg, hogy biológiailag a Homo sapiens fajba tartozik, ellentétben az (emlős) állatokkal. Ez szerinte igazolhatatlan és önkényes faji megkülönböztetés, amelynek alapján az emberi fajnak az élethez való jogot tulajdonítják, amelyre azonban az állati faj(ok) nem jogosult(ak). Peter Singer: Animal liberation. London, Pimlico, 1995. 18. 
van. ${ }^{102}$ Az emberi személyt nem észhasználata (és még csak nem is annak potencialitása), hanem a méltóságát eredményező lelke teszi személlyé, s ez a létezők lényegét firtató filozófiai kutatás által is megállapítható azon túl, hogy az Isten által teremtett emberi lélek létezése a keresztény teológia sarokköve. ${ }^{103}$ Minden emberi képességgyakorlás, azaz a gondolkodás, az erkölcsi döntés stb. csak már olyasvalakinek az aktusai, aki már előzetesen tételezve létezik. Fogalmilag tételezni kell őt, hiszen ha nem létezne, akkor nem tudná e cselekedeteket végezni, s az erre való potenciális képes-

102 Kevin D. O’Rourke: The Embryo as Person. The National Catholic Bioethics Quarterly, 6. (2006), 2. 241-251. Természetesen nem lehet „empirikusan” bizonyítani azt, hogy a fogantatás pillanatában kerül az emberi lélek az emberi embrióba (a lélek létezését eleve is nehezen lehetne így pozitivista eszközökkel megragadni), azonban minden más érvelés, amely nem azt tartja, hogy a fogantatáskor kerül bele, nem védhető teoretikusan. Azaz filozófiailag csak az helyes érvelés, hogy a fogantatásakor lelkesül át a méhmagzat. A valóság is ez tehát, hiszen a filozófia a valóságot bizonyítja koherens érvekkel, elméleti eszközökkel.

103 Robert P. George szerint nem szükséges az „átlelkesülés” és a születés előtt meghaltak örök sorsának teológiai kérdéseihez fordulni ahhoz, hogy a magzat új emberi élet voltából fakadó erkölcsi értékét és teljes méltóságát alá lehessen támasztani meggyőző érvekkel, mivel az említett teológiai kérdések irrelevánsak a morális vita és a helyes public policy vitele szempontjából. Mivel a magzat ugyanaz a teljes ember, mint az újszülött, a serdülő vagy a felnőtt, csak természetes fejlődésének nagyon korai, még éretlen szakaszában, így emberi lényként ugyanazon Homo sapiens fajhoz tartozik, s létezésében nem egy másik biológiai szervezet része. Szerinte bőven elégséges az alapvető vonatkozó filozófiai elveket az embriológia új természettudományos ismereteire alkalmazni. George i. m. (75. lj.) 154-155. Possenti viszont arra mutat rá helyesen, hogy az alapvető jogok az embert nem (biológiai értelemben vett) emberként, hanem emberi személyként illetik meg. Nézetünk szerint a személy mivoltot az ember lelke, s nem racionalitása alapozza meg, s nem is a racionalitás potencialitása, későbbi kialakulásának lehetősége. Manapság, főleg a német teológia irányvonalából érkező hatások miatt, az érzékelhető, hogy mind a - görög filozófiai eszmetörténeti behatással is bíró - lélek, mind a személy fogalmának alkalmazása tekintetében egyfajta óvatosság, visszafogottság van jelen bizonyos tekintetben a katolikus morálfilozófiában is. Ez érthető módon különösképpen jelentős hatással bír az ember magzati fejlődési státuszának ontológiai meghatározásakor, különösen, hogy az animáció tana körüli filozófiai viták eleve nehézzé tették a magzat személy voltának pontos időbeli meghatározását.

Nézetünk szerint az Egyház nem állítja azt, hogy bármilyen értelemben problémás lenne a magzat személy volta, hanem a tanítóhivatal csak annyit jelent ki, hogy nem köteleződik el kifejezetten filozófiai személyfogalmak mellett, illetve hogy még akkor is a legszigorúbb életvédelem illeti meg a magzatot, ha csak feltételezhető lenne a személy volta. L. A Katolikus Egyház Katekizmusa, 2274., 2270.; Donum vitae I, 1.; Evangelium vitae III, 60.; Dignitas personae I, 5. A magzat tehát lélekkel rendelkező emberi személy, aki ilyen feltétlen személyi méltósággal bír, s életéhez joga van a katolikus tanítás szerint, amely gyakorlatilag a szimultán vagy azonnali animációt, vagyis a magzat fogantatásának pillanatában való „átlelkesülését” vallja. A Hittani Kongregáció 1974-es Dichiarazione sull'aborto procurato dokumentuma csak utal az animáció körüli sok évszázados filozófiai vitára. A pápai életvédő akadémia (Pontificia Accademia per la Vita) XII. közgyűlésének záródokumentuma pedig egyértelmüen leszögezi, hogy nincsen olyan jelentős érv, amely a magzat személy voltát tagadhatná. (Bár a dokumentum tartalmazza azt az érvet is, hogy pusztán az emberi személyi lét jelenlétének valószínűsége is elég lenne a magzat életének legszigorúbb védelméhez.) A nyilatkozat leszögezi, hogy a magzat személylétét alátámasztó közvetlen animáció tana van teljes összhangban az újonnan létrejött emberi lény biológiai valóságával. A pápa védnöksége mellett működő, az emberi élet védelmével tudományosan foglalkozó egyházi grémium tehát kijelentette, hogy az emberi magzat lélekkel bíró emberi személy. 
sége sem lenne, hiszen minden cselekvési képesség csakis valakinek a képessége lehet, hogy tegyen valamit.

Nem a képesség gyakorlása vagy annak merő (potenciális/elvi) képessége teszi tehát őt emberré, hanem mivel létező és élő ember, ezért adott esetben képes ezen aktusokra, avagy éppen nem valamiféle belső vagy külső akadályoztatás miatt. Egyes kutatók szerint - ideértve katolikus morálteológusokat is - az Egyház hivatalos dokumentumában nem nyilvánította ki még teljes egyértelműséggel, hogy a méhmagzat, azaz az embrió átlelkesülése teljes bizonyossággal a fogantatás pillanatában történne, s ezért az már emberi személy lenne, minthogy ez filozófiai kérdés, akkor erre azt lehet mondani, hogy a filozófia teljes bizonyossággal állíthatja, hogy az emberi embrió a fogantatása pillanatától kezdve egyedi szellemi lélekkel rendelkező emberi személy. Ennek filozófiai bizonyítása tehát megtörtént. Egyes helyes bioetikai szemléletet mutató katolikus kutatók is kijelentik már ezt, mégpedig bioetikailag igazolható kijelentésként. Tekintsük viszont át előbb a kortárs, e tárgykört érintő bioetikai nézetek főbb állításait!

\section{Kortárs mainstream utilitarista és libertárius bioetikai elméletek az emberi és nem emberi életről, az ember alanyiságáról és a méltóságról}

Az utilitarista és a libertárius bioetikai elméletek az élő emberi test létezését leválasztják az emberi személyiség létéről. Ennek következtében azt állítják, hogy az emberi test életében vannak oly életfázisok, amelyekben e testhez nem kapcsolódik emberi személyiség. Az emberi személy létrejöttét az utilitarista elméletek minimálisan a fogantatástól számított 14. napra teszik, amikor az érzések észlelésének képessége minimális szinten már érvényesül, vagyis amikor a kezdetleges barázdálódás, a központi idegrendszer kezdeménye létrejön, legvégső időpontként pedig a fogantatástól számított 18. hétre, mikor teljes mértékben kifejlődött már a központi idegrendszer, amely ahhoz szükséges feltétel, hogy a magzat az örömet és a fájdalmat érezze. A libertárius elmélet az önmeghatározás képességét tekinti a személyi lét feltételének, részben a felvilágosodás kori - például a locke-i - az ember „saját személyén való jogának” és az ember Immanuel Kant által megfogalmazott autonómiájának a félreértésével vagy talán inkább félremagyarázásával. Ez az elmélet az önrendelkezést tekinti tehát olyan kritériumnak, amelyhez a személystátusz juttatása kötendő. Ennek megfelelően minimális szinten az agykéreg kiformálódásának mozzanatához (22. hét) köti a személyiség létrejöttét, amely annak neurofiziológiai feltétele, hogy a racionalitás képességét gyakorolhassa; maximális mértékben pedig akkor ismeri el a személyiség létrejöttét, amikor az alanyban, illetve a „morális cselekvőben” az öntudat észlelésének/ gyakorlásának képessége megjelenik (azaz az emberi élet születés utáni időszakában).

Az élet vége kérdése tekintetében pedig az mondható el, hogy a fenti elméletek kizárják az alanyiság meglétét azon individuumokban, amelyek bár biológiai testben élnek, túlságosan szenvednek, vagy másoknak okoznak túl sok szenvedést azáltal, hogy nem tudják a szenvedésüket enyhíteni, s öntudatlanok, azaz nem rendelkeznek bár- 
miféle agykéreg-tevékenységgel, azaz bár vegetatív funkcióik működnek, képtelenek az öntudatosságra, a racionalitásra és az erkölcsi döntésre. A libertárius és utilitarista elméletek tehát az emberi test biológiai létezéséhez képest leszúkítik az alanyiság meglétét: a személyiség kialakulását az emberi test biológiai keletkezéséhez képest későbbre helyezik, illetve az emberi személyiség korábban megszűnhet az emberi test (biológiai) halálához képest. Továbbá előfordulhat az is ebben a koncepcióban, hogy olyan emberi lények is élnek testükben biológiai értelemben életet, akiknek személyiségét soha nem ismerik el (nagyon súlyos központi idegrendszeri károsodással való születés esetén), vagy amely személyiség valamely alapvető emberi funkciók gyakorlása működésének megszűntével időlegesen (tartós kóma, amelyből van esély a felébredésre) vagy véglegesen megszűnik. E teoretikus alapállások bioetikai és jogfilozófiai következménye az, hogy az emberi lények olyan kategóriáit tételezik, akik bár biológiai értelemben élnek, de nem rendelkeznek személyiséggel, és így méltósággal sem. Az emberi embriók és a magzatok, de a csecsemők és a kisgyermekek sem rendelkeznek még alanyisággal, a kómába esett egyének, agykárosodottak, demensek, idősek, szellemi fogyatékkal élők, de a nagy fájdalommal élők sem személyek márr. ${ }^{104}$

A test és a személyiség szétválasztásának gyökerénél az a szemléletmódbeli alapállás található, hogy a testet e megközelítésmódot vallók tárgyiasították, azaz alanytalanították, ami voltaképpen az emberi méltóság emberi testből való kivételét jelenti. A biológiai test tárgyiasítása a test szcientista redukciós szemléletéből fakad, amely szerint az térben kiterjedő, mozgó organikus matéria, azaz tér- és időkoordinátákban leírható, egymással kapcsolatban levő sejtcsoportok, illetve azok aggregátumainak összessége. Ezek szövetekké és szervekké differenciálódnak biokémiai és genetikai információkat közvetítve egymás felé morfológiai, funkcionális és neurofiziológiai komplexifikáció szerint, amelyeket az okhatás törvénye szabályoz. ${ }^{105}$ Ezen redukcionista szemléletmód nem pusztán arra szorítkozik, hogy leírja empirikus módon a test mủködését, hanem azt állítja, hogy ez a tudományos és az egyetlen helyes leírási módja a test mibenlétének, tagadván tehát azt, hogy létezhet ezt meghaladóan egy másik dimenziója is az emberi testnek.

Ennek tarthatatlan egyoldalúsága rögtön nyilvánvalóvá válik, ha a kegyeleti jogokra gondolunk, amelyek olyan, immáron elhunyt személyhez tartoznak, aki nyilvánvalóan nem él már. Mennyivel inkább teljesen áthatja tehát az élő emberi személy testét e személy méltósága annak minden létállapotában. Sőt majdhogynem a mindenki által könnyen érzékelhető, ugyanakkor a társadalom által könnyen sérthető teste jeleníti meg elsőrendủen a külvilág felé a személyi méltóságát. Nem is véletlen az - ahogy már korábban utaltunk rá -, hogy az emberi méltóság védelmének a legrégibb és egyben a leginkább bevett védelmi dimenziója az emberi személy testének védelme mindenféle kínzással vagy bármiféle embertelen bánásmóddal szemben. Az ember ember mivolta, méltósága, maga a humanitás elsőrendűen az emberi személy testének,

104 Laura Palazzani: La filosofia per il diritto. Teorie, concetti, applicazioni. Torino, Giappichelli, 2016. 158.

105 Uo. 159. 
minden ember testének - ideértve a bűnözőket és a terroristákat is - védelmében ölt normatív alakot, s írja elő az emberi méltóságnak az emberi testben, azon keresztül történő abszolút jogi védelmét. Az emberi személy ugyanis testében él, $\mathrm{s}$ ezért annak humanitását érintő sértése, megalázása az emberi személy mivolt, azaz a méltóság sérelme.

A kegyeleti jogok léte újabb dimenzióban emeli fénybe az ember, akár holt testében is tetten érhető személyi méltóságát. Ezzel szemben az imént tárgyalt szcientista redukció képviselői azt vallják, hogy a kiterjedés és a mozgás mechanikus mennyiségi mérése révén tudományos empirikus módon megismerhető tényadatokkal lehet egyedül hiteles módon leírni, megragadni az emberi test mibenlétét, s ezért tagadják mindazon dimenziók és valóságok létét az emberben, amelyek így nem ismerhetők meg, azaz az emberi minőségek, a természeti lényegek és az emberi természetben rejlő célok létezését. ${ }^{106}$

A most tárgyalandó mainstream bioetikai koncepcióban a puszta tárggyá redukált emberi test létezésének különféle stádiumaihoz társul az emberi alanyiság, másokban pedig az megszűnik létezni. Az alanyiság e koncepcióban tehát - mutat rá helyesen Laura Palazzani - a mennyiségi dimenziójára csupaszított emberi test egyfajta külső minősitésévé válik. Ezen alanyiság létrejön az emberi biológiai szervezet meghatározott szintjeire való fejlődésével, majd megszűnik az onnan való visszafejlődésével. E koncepciókban általános tendenciának tekinthető az ember alanyiságának „testetlenedése",107 illetve, a másik oldalról, annak bizonyos emberi biológiai funkciók meglétéhez, azok effektív gyakorlásához kötése ${ }^{108} \mathrm{~s}$ ugyanakkor azokban történő kimerülése. Azon egyéneket tekintik következésképpen személyeknek, akik ténylegesen képesek bizonyos relevánsnak tartott funkciók gyakorlására: ezek a fájdalom érzékelésének képessége, amely megalapozza azt, hogy legyenek az alanynak (a fájdalom elkerülésére irányuló) érdekei, a racionalitás, az autonómia, az akarás és az önrendelkezés képessége. Azok minősülnek alanyoknak, akiknek testi müködésében e funkciók meglétének külső megnyilvánulásai tetten érhetők. Nem minden biológiai élettel bíró emberkategória van e helyzetben, miközben nem pusztán emberek képesek - szerintük - e funkciók gyakorlására, hiszen bizonyos fejlett emlősök és nagyon magas szintű

106 Uo.

107 Uo.

108 Tévednek mindazok, akik konkrét képességek gyakorlásához kötik az ember személyi létét, az ember alanyiságának (személyiségének), s ezért méltóságának meglétét. Még sajnos Martha Nussbaum is beleesik abba a hibába, hogy mivel teljesen helyesen azért küzd, hogy a fogyatékkal élők jogai ne elvont deklarációk legyenek, hanem hogy azok ténylegesen többlet-képességgyakorlásban öltsenek testet, ezért inverz módon a képességek konkrét gyakorolhatóságához köti az emberi méltóság meglétét. Vö. János Frivaldszky: Dignità, soggettività e capacità giuridica delle persone con disabilità - riflessioni critiche partendo da Martha Nussbaum. In Paolo Heritier - Pierangelo Sequeri (szerk.): Deontologia del fondamento: Seguito da Verso una svolta affettiva nelle law and humanities e nelle neuroscienze. Torino, G. Giappichelli, 2016. 259-315. Helyes megközelítésben az emberi lélek az elsődleges, amelynek kontingens másodlagos kifejeződései a cselekvési képességek, s így értéküket is az előbbiből nyerik. Paola Bernardini: Uomo naturale o uomo politico? Il fondamento dei diritti in Martha C. Nussbaum. Soveria Mannelli, Rubbettino, 2009. 59. 
technológiával, mesterséges intelligenciával rendelkező robotok is produkálhatnak ilyen funkciókat, vagyis „nem humán állatok” és „poszthumán alanyok” is lehetnek személyek e bioetikai koncepcióban. Az utilitarista, amiképpen a transz- és poszthumanista irányzatok is, meg kívánja haladni az ember állatokkal szembeni ontológiai magasabbrendűségének tézisét. Mivel az élőlények fájdalomérzékelő képességét tekintik a személyi lét központi elemének, így a legfejlettebb emlősállatok esetében is tételezik a személyi létet, ekképpen egyes képviselőik élesen kritizálják az ember és állat közötti antropocentrista „faji diszkriminációt”, amelyet az állatok kárára történő teljesen indokolatlan diszkriminatív különbségtevésnek tekintenek.

Szerintük a „nem emberi állat” és az „emberi állat” teste között nem tehető lényegi különbség, minthogy mindkettőjük szervezete képes a központi idegrendszere révén a fájdalomérzékelésre, s ezért a kellemes külső ingert keresik, s a fájdalmasat pedig elkerülni igyekszenek. Már az imént említett kategóriaképzések is („nem emberi állat” és „emberi állat”) beszédesek: az ember az erkölcsi bánásmód etikája szempontjából is csupán egy állati faj, csak egy a fejlett emlősök fajai közül. Az utilitarizmus számára nem az emberi létmód, hanem a külső ingerekre kellemes vagy fájdalmas érzetekkel reagálni képes érző test megléte a kulcskérdés, legyen az emberi vagy nem emberi (fejlett emlősállati) test, s ez az, ami az alanyiságot - szerintük - létrehozza.

A libertárius koncepciókban pedig a mesterséges intelligenciával (vagy akár esetleg érzőképességgel is?) rendelkező robot is alanynak minősülhet. Nem létezik tehát a lényeget érintő különbség az emberi lény biológiai teste és a mesterséges intelligencia között, amennyiben mindkettő felmutatni képes az alanyra jellemző alapvető funkciók, vagyis az öntudat, a racionalitás és az önrendelkezés meglétét. A transzés a poszthumanizmus képviselői kitágítják az alanyiságot az „emberin” és az organikus létezőn túlra oly módon, hogy az magában foglal új virtuális, kibernetikus, szintetikus, nem organikus és nem élő alanyokat is. ${ }^{109}$ Ezen általuk vázolt és vágyott jövőképben a konvergens technológiák (nanotechnológiák, biotechnológiák, informatika, kognitív tudományok) révén a biotechnológiai komponensek merő fogadóivá redukálódván ki fognak üresedni a testek. ${ }^{110}$ Azon igyekezetben történik ez, hogy elérjék és létrehozzák a „»technohumán« létmódot, amely meghaladja a biológiai, fizikai és mentális korlátokat az ember és a gép fúziójában (cyborg), vagy automatizált

109 Palazzani i. m. (104. lj.) 160.

110 A konvergens tudományok alkalmazásával a bio- és géntechnológiát a transz- és poszthumanizmus képviselői nem terápiás célból, azaz a sérült emberi funkcionális kapacitás helyreállítása célból kívánják használni, hanem arra, hogy ideológiai vagy pusztán fogyasztói szemlélettől indíttatva meghaladják a jelen emberi természet szerintük kiküszöbölendő hibás tulajdonságait (ideértve a fájdalmat, az ember nemkívánatos személyiségjegyeit, illetve magát a halált is), hogy azt jobbítva, fokozva, „potenciálva” (enhancement) távlatilag egy genetikailag új, poszthumán fajt (new breed) hozzanak létre, pontosabban „tenyésszenek ki” az emberből. Vö. Frivaldszky János: Transhumanismo y dignidad - mejoras terapéuticas y no terapéuticas. In Miguel Ayuso (szerk.): ¿Transhumanismo o posthumanidad? la política y el derecho después del humanismo. Madrid, Marcial Pons, 2019. 139-155. 
és önállóvá tett gépek tervezésével, amelyek a hús-vér embert helyettesítik a halhatatlanság és a korlátlan tökéletesség ígéretével."111

\section{Az ember és méltósága a halálakor}

Az ember életének és halálának jogi fogalma egyrészt annak biológiai-orvosi, másrészt a közbeszédben használt értelméhez szorosan kötődik. Az ember halála (a másik ember megölése, illetve halálának okozása vagy általában az alany halála) számos tekintetben jogi minőséggel, jogkövetkezménnyel bír, s mivel az ember létének végét jelenti, ezért alapjogokat, azok meglétét és gyakorolhatóságát szükségképpen érinti. Az ember létének, életének védelme minden jogrendszer alapja, értelme és célja, minthogy a jog minimális funkciója az ember védelme és az emberi társadalom fennmaradásának biztosítása. A kortárs jogelméletre talán a legnagyobb hatást gyakorló, jogelmélettel foglalkozó jogász, Herbert Hart alapvetően hibásnak bizonyult elméleti rendszerének elméleti tanulságai arra mutatnak rá, hogy az emberi életet csak akkor lehet hatásosan jogi - elméletalkotási - eszközökkel védeni, ha az embert és annak életét, valamint annak erőszakos elvételét is ontológiai, metafizikai alapokon ragadjuk meg teoretikusan, s akkor az életének védelme is, illetve az erőszakos halál megelőzésének kérdése is természetjogi alapokon fog állni. ${ }^{112}$

Az emberi élet jelentőségének összefüggésében szemlélt halál fogalmának meghatározása azért is elemi jelentőségű, mert jobbára annak tudatosításán keresztül biztosítható az ember életének megfelelő védelme. Azonban a „mi a halál?” definiálása helyett a redukcionistább „mikor következik be a halál?” kérdés megválaszolása felé terelődött az utóbbi időben az orvosok, így a jogászok érdeklődése is. Ennek eredményeképpen a halál teljesebb értelmű kérdése elsikkadt, különösen, hogy manapság sajnálatosan az emberi személy és annak életének helyes értelmű fogalmi megadása sem áll a jogfilozófiai érdeklődés homlokterében. A halál jelenségének megértése ennek következtében annak beálltának biológiai-orvosi vagy a hétköznapi gondolkodásban tetten érhető megközelítésére redukálódott. Azt láthatjuk, hogy az orvostudomány aktuális állása és az abban futó gondolkodási „paradigmák”, illetve az abban megjelenő orvosi és egyéb emberi érdekek (szervátültetés megkönnyítése és felgyorsítása a frissen halottá nyilvánított személyből vagy éppen az életben tartás anyagi ráfordításának költségei) nagymértékben meghatározzák a halálról való közgondolkodás alakulását, ami pedig megszabja az ez irányú jogi gondolkodás főbb irányait is. Figyelemmel kell lenni arra, hogy a jog tartalma legtöbbször érdekek ütközésekor nyilvánul meg érvelésekben, jogeseteken keresztül, s e logika mentén fejlődik, változik. Következésképpen a halál jogi megítélése is elsősorban nem akadémikus viták tárgyaként formálódik. A jogász feladata azonban az, hogy e gyakorlati jogi és egyéb érdekek szövevényében tisztára csiszolja az emberi halál jogi szemléletü

111 Palazzani i. m. (104. lj.) 160.

112 Frivaldszky i. m. (9. lj.) 280-308. 
valóságát, különösen, hogy az ember legalapvetőbb védelmének legkritikusabb eseményéről, vitális körülményeiről van szó.

Amíg a szívműködés és a légzés nem bizonyult funkcionálisan mesterségesen pótolhatónak, addig azok megszűnése jelentette a halál beálltát, manapság pedig, mivel ez már biztosítható, az agymủködés kritériumainak megléte tölti be ezt a funkciót, vagyis az előbbiek már nem elégséges kritériumok. Az agyhalál kritériumegyüttese révén azonosítható tehát manapság a halál beállta, ami sokkal inkább egy állapot, semmint egy pontosan meghatározható időpont. Már csak azért sem, mert az agyműködés neurológiai-fiziológiai, a test működése szempontjából integratív funkciójának megléte binárisan nem állapítható meg, azaz egyértelmű és végérvényes kritériumként nem alkalmazható, hacsak nem alkalmazunk egy különbségtételt az életfunkciókban úgy, hogy vannak magasabb, alapvetőbb és alacsonyabb szintű, kevésbé lényegi biológiai funkciók. Továbbá az agy halálának is többirányú, párhuzamos értelmei terjedtek el, nem is beszélve arról, hogy az „agyi” müködés sem lokalizálható egyetlen szervi helyre, miközben az agy- és idegtudományok magát az így értett agyfunkciót sokszor a teljes emberi létmóddal azonosítják, ami nagymértékủ redukálása az ember életének.

Szükség van ennek következtében egyrészt biológiai értelemben is egy jóval komplexebb szemléletmódra az összes szóba jövő élettani kritérium figyelembevételével. ${ }^{113} \mathrm{~A}$ teljes és visszafordíthatatlan agyhalál, amely az emberi szervezet egységének felbomlását jelentené, nem tủnik elégséges kritériumnak a halál megállapítására, bár sokan, köztük még katolikus, jogfilozófiával és bioetikával foglalkozó jogászok is emellett teszik le a voksot. ${ }^{114}$ Ezenkívül égető szüksége van a jogásznak is arra, hogy az emberi élet létezését ne a központi idegrendszeri és agyműködésbeli funkciók működésére szorítottan tekintse, hanem hogy az életet és a halált magát is az emberi léttel, annak szellemi és lelki vonatkozásainak összhangjában, azokkal összefüggésében ragadja meg, mert egyébként nem tudja az emberiszemély-jelleget semmiképpen sem konceptualizálni, aminek következtében pedig az emberi élettel ellentétes gyakorlatokat lesz kénytelen elfogadni.

Azt kívánjuk érzékeltetni, hogy azt a legkomplexebb összefüggésben szemlélt kérdést, hogy mikor következik be ténylegesen az ember halála, csakis akkor tudjuk megválaszolni, ha előzetesen fogalmilag azt tisztáztuk, hogy mit is jelent, miben is áll az ember halála, ami pedig csak abban az esetben tematizálható adekvát módon, ha már előzetesen tudatosítottuk, hogy miben áll az ember élete, létének jogfilozófiai módon is releváns lényege. Mivel azonban az ember jogi fogalmának meghatározására manapság már nem is törekednek a jogászok, mivel az emberi személy és az em-

113 Abigail Maguire: Towards a Holistic Definition of Death: The Biological, Philosophical and Social Deficiencies of Brain Stem Death Criteria. The New Bioethics, 25. (2019), 2. 172-184.

114 Vö. D’Agostino-Palazzani i. m. (87. lj.) 119. Wolfgang Waldstein ezzel szemben vehemensen utasítja el ezt az alapállást jogfilozófiai és katolikus doktrinális érvekkel, a vonatkozó egyházi dokumentumokra hivatkozva, $\mathrm{s}$ az ezzel ellentétes értelmezési és értelemadási tendenciákra, azok hibás voltára is rámutatván, sokszor egyes vonatkozó dokumentumok keletkezési kontextusát is feltárva. Waldstein i. m. (58. lj.) 119-132. 
beri méltóság túlságosan is metafizikai fogalmaival nem tud mit kezdeni a kortárs jogi gondolkodás, ezért természetszerűleg a halál fogalmi megragadása sem járhat biztos úton. Annál is kevésbé, mivel időközben az idegtudományok a mesterséges intelligencia kutatásának eredményeképpen olyan magas szintre fejlődtek, hogy már az agyműködés is sok tekintetben kiválthatónak tünik, ezért nincsen olyan biológiaifiziológiai funkció az emberben, amit ne lehetne mesterségesen pótolni, előállítani.

Ha már a szív- és a légzésmüködés mesterséges módon való biztosíthatósága után az agyi központi idegrendszeri feladatok bizonyos része is reprodukálható, akkor a pusztán gondolkodó lénynek, sőt ilyen gondolkodó állatfajnak tekintett ember halála sem tűnik biológiailag szükségszerünek, hanem annak időpontja kitolható, variálható, illetve akár (elméletben) mesterségesen ki is küszöbölhető mindaddig, ameddig a halál pusztán neurológiai-fiziológiai folyamatok eredményének tủnik, s olybá tekintenek rá. Ez esetben azonban nem tekintettük azt, hogy mi a sajátlagosan emberi az emberi életben, azaz az mitől emberi, s mi ér tulajdonképpen véget emberi valóságként az ember halálával. Ezért tehát - ebben a koncepcióban - semmi sem marad az emberben, ami igazán, sajátlagosan emberi lenne természeti lényege szerint.

A helyes jogfilozófiai gondolkodás ezzel szemben az ember filozófiai, antropológiai lényegére fókuszál, amelyben az emberi értelem mint életértelem túlmutat az ember agyműködésén, $\mathrm{s}$ az ember szellemi lelke, amely az ember igazi lényege, még ezt is meghaladja metafizikai jellegében: mindvégig jelen van, ameddig a konkrét egyén meg nem halt, de léte nem a biológiai test emanációja, származéka, így nem is detektálható természettudományos eszközökkel, pozitivista tudományos módszerekkel. Ezért van szüksége a jogi gondolkodásnak is a morál- és a természetjogias jogfilozófiai gondolkodás e téren nyert alapkutatási eredményeire. Nézetünk szerint az emberi személy ilyen fogalmi megragadásából lehet csak helyesen definiálni az ember halálát és jogilag szabályozni az ezzel összefüggő jogi kérdéseket.

\section{Irodalomjegyzék}

Ambrosetti, Giovanni: Diritto naturale cristiano, profili di metodo, di storia e di teoria. Róma, Studium, 1970.

Ayuso, Miguel (szerk.): La autodeterminación: problemas jurídicos y políticos. Madrid, Marcial Pons Ediciones Jurídicas y Sociales, 2020. DOI: https://doi.org/10.2307/j.ctv10rrcvs

Bernardini, Paola: Uomo naturale o uomo politico? Il fondamento dei diritti in Martha C. Nussbaum. Soveria Mannelli, Rubbettino, 2009.

Bloch, Ernst: Naturrecht und menschliche Würde. Frankfurt, Suhrkamp, 1961.

Bobbio, Norberto: Sul fondamento dei diritti dell'uomo. Rivista Internazionale di Filosofia del Diritto, 42. (1965), 302-309.

Bobbio, Norberto: L'età dei diritti. Torino, Einaudi, 1997.

Busnelli, Francesco D.: Rilevanza giuridica della vita prenatale, categorie civilistiche, principi costituzionali. In Donato Carusi - Silvana Castignone (szerk.): In vita, in vitro, in potenza: lo sguardo del diritto sull'embrione. Torino, Giappichelli, 2011.

Calvez, Jean-Yves: I diritti dell'uomo secondo Maritain. In Aucante, Vincent - Papini, Roberta (szerk.): Jacques Maritain: la politica della saggezza. Soveria Mannelli, Rubbettino, 2005. 
Capehart, James: Incarnate Spirit. Proper Thomistic Definition of the Human Being or Merely Description of the Human Soul? In Conley, John J. (szerk.): Redeeming Philosophy. From Metaphysics to Aesthetics. Washington, American Maritain Association, 2014. 83-98.

Carbone, Giorgio M.: L'embrione umano. Qualcosa o qualcuno? Bologna, Studio Domenicano, 2014.

Castellano, Danilo: Razionalismo e diritti umani. Dell'antifilosofia politico-giuridica dell "modernità". Torino, Giappichelli, 2003.

Catalano, Pierangelo: L’inizio della „persona umana” secondo il diritto umano. In Trisciuoglio, Andrea (szerk.): Valori e principii del diritto romano. Napoli, Scientifiche Italiane, 2009.

Coccopalmerio, Domenico: Fortitudo Iuris. Persona e diritto. Trieszt, LINT, 1989.

Commissione Teologica Internazionale: Alla ricerca di un'etica universale: nuovo sguardo sulla legge naturale. Vatikán, Libreria Editrice Vaticana, 2009.

Costello, Stephen J.: Logotherapy as Philosophical Practice. In Sárkány Péter - Vik János (szerk.): Logoterápia és Egzisztenciaanalízis, 7. (2015), 3. 122-153.

Costello, Stephen J.: The Spirit of Logotherapy. Religions, 7. (2016), 3.6. DOI: https://doi.org/10.3390/ rel7010003

D’Agostino, Francesco - Palazzani, Laura: Bioetica. Nozioni fondamentali. Brescia, La Scuola, 2016.

D’Agostino, Francesco: Il Diritto come problema teologico. Torino, G. Giappichelli, 1995.

D’Agostino, Francesco: A természetjog kérdése az egyház társadalmi tanításában. In Frivaldszky János: Természetjog. Szöveggyüjtemény. Budapest, Szent István Társulat, 2006. 257-271.

D’Avenia, Marco: La conoscenza per connaturalità in S. Tommaso d'Aquino. Bologna, Studio Domenicano, 1992.

Donati, Alberto: Giusnaturalismo e diritto europeo, human rights e Grundrechte. Milano, Giuffrè, 2002.

Engelhardt, H. Tristram: Manuale di bioetica. Milánó, Il Saggiatore, 1999.

Fabricius, Fritz: Relativität der Rechtsfähigkeit. Ein Beitrag zur Theorie und Praxis des privaten Personenrechts. München-Berlin, Beck, 1963.

Fagot-Largeault, Anne: The Notion of the Potential Human Being. In Bromham, David R. - Dalton, Maureen E. - Jackson, Jennifer C. (szerk.): Philosophical ethics in reproductive medicine. Manchester, Manchester University Press, 1990. 149-155.

Fagot-Largeault, Anne: Abortion and Arguments from Potential. In Gillon, Raanan (szerk.): Principles of Health Care Ethics. London, Wiley, 1993. 577-586.

Fagot-Largeault, Anne: L'embryone umano come persona in potenza. In Agazzi, Evandro (szerk.): Bioetica e Persona. Milánó, Franco Angeli, 1993. 158-174.

Finnis, John: Misunderstanding the Case against Euthanasia: Response to Harris's First Reply. In Keown, John (szerk.): Euthanasia Examined: Ethical, Clinical and Legal Perspectives. Cambridge, Cambridge University Press, 1999. DOI: https://doi.org/10.1017/CBO9780511663444.008

Frankl, Viktor E.: Értelem és egzisztencia. Előadások és tanulmányok. Budapest, Jel, 2006.

Frivaldszky, János: Diritto naturale senza natura umana? In Malo, Antonio (szerk): Natura, cultura, libertà: storia e complessità di un rapporto: comunicazioni del convegno della Facoltà di filosofia 2010, Pontificia Università della Santa Croce. Róma, EDUSC, 2010. 113-123.

Frivaldszky János: Természetjog és emberi jogok. Budapest, Pázmány, 2010.

Frivaldszky, János: Diritti umani e natura umana. In Maspero, Giulio - Laborda, M. Pérez de (szerk.): Fede e ragione: l'incontro e il cammino: In occasione del decimo anniversario dell'enciclica Fides et Ratio. Siena, Cantagalli, 2011. 149-158.

Frivaldszky, János: Law as Practical Knowledge: Deconstruction, Pragmatism, and the Promise of Classical Practical Philosophy. In Martinengo, Alberto (szerk.): Beyond Deconstruction: 
Az ember jogalanyiságának, életéhez és méltóságához való joga...

From Hermeneutics to Reconstruction. Berlin, De Gruyter, 2012. 255-275. DOI: https://doi. org/10.1515/9783110273328.255

Frivaldszky, János: Quale legge naturale per l'Europa dopo la scuola neoclassica del diritto naturale? In Fracanzani, Marcello M. - Baroncelli, Stefania (szerk.): Quale religione per l'Europa? Nápoly, Scientifiche Italiane, 2014. 51-72.

Frivaldszky, János: Legal Discourse: The Promise of Classical Practical Philosophy. In Manzin, Maurizio -Puppo, Federico - Tomasi, Serena (szerk.): Studies on Argumentation and Legal Philosophy: Further Steps towards a Pluralistic Approach. Trento, Università degli Studi di Trento, 2015. 129-142.

Frivaldszky, János: Dignità, soggettività e capacità giuridica delle persone con disabilità - riflessioni critiche partendo da Martha Nussbaum. In Heritier, Paolo - Sequeri, Pierangelo (szerk.): Deontologia del fondamento: Seguito da Verso una svolta affettiva nelle law and humanities e nelle neuroscienze. Torino, G. Giappichelli, 2016. 259-315.

Frivaldszky János: A jogfilozófia alapvető kérdései és elemei. Budapest, Szent István Társulat, 2019.

Frivaldszky, János: Transhumanismo y dignidad - mejoras terapéuticas y no terapéuticas. In Ayuso, Miguel (szerk.): ¿Transhumanismo o posthumanidad? la política y el derecho después del humanismo. Madrid, Marcial Pons, 2019. 139-155. DOI: https://doi.org/10.2307/j.ctv10rrcg3.13

Fukuyama, Francis: Poszthumán jövendönk. A biotechnológiai forradalom következményei. Budapest, Európa, 2003.

Gardner, Elinor: Nature and Rights: The Meaning of a Universal Agreement on Human Rights. In Butera, Giuseppe (szerk.): Reading the Cosmos: Nature, Science, and Wisdom. Washington, American Maritain Association, 2012. 215-228.

George, Robert P.: Il diritto naturale nell'età del pluralismo. Róma, Armando, 2006.

Hegedűs Katalin: Létezik-e jó halál? Budapest, Oriold, 2017.

Hennezel, Marie de - Leloup, Jean-Yves: A halál müvészete. Hogyan nézzünk szembe a halállal? Vallási hagyományok és humanista spiritualitás napjainkban. Budapest, Európa, 1999.

Huxley, Julian S.: Religion without Revelation. New York - London, Harper and Brothers, 1927.

Huxley, Julian: New Bottles for New Wine. London, Chatto and Windus, 1959.

Kelsen, Hans: Tiszta jogtan. Budapest, ELTE Bibó Szakkollégium, 1988.

Lagrotta, Ignazio: Il diritto alla vita e i diritti fondamentali dell'embrione. In Tarantino, Antonio (szerk.): Culture giuridiche e diritti del nascituro. Milánó, Giuffrè, 1997.

La Torre, Massimo: Disavventure del diritto soggettivo. Milánó, Giuffrè, 1996.

Lauriola, Giovanni: La persona: storia di un concetto. In Lauriola, Giovanni (szerk.): Diritti umani e libertà in Duns Scoto. Alberobello (Bari), A.G.A., 2000. 125-150.

Maguire, Abigail: Towards a Holistic Definition of Death: The Biological, Philosophical and Social Deficiencies of Brain Stem Death Criteria. The New Bioethics, 25. (2019), 2. 172-184. DOI: https://doi.org/10.1080/20502877.2019.1606148

Maritain, Jacques - Maritain, Raïssa: Euvres complètes. Fribourg-Párizs, Éditions Universitaires - Saint-Paul, 1988.

Maritain, Jacques: Nove lezioni sulla legge naturale. Milánó, Jaca Book, 1985.

Maritain, Jacques: Il significato dei diritti umani. In Maritain, Jacques: I diritti dell'uomo e la legge naturale. Milánó, Vita e pensiero. 1993. 121-149.

Maritain, Jacques: Az igazi humanizmus. Budapest, Szent István Társulat, 1996.

Maritain, Jacques: La persona e il bene comune. Brescia, Morcelliana, 1998.

Maritain, Jacques: Man and the State. Washington, Catholic University of America Press, 1998. 
Maritain, Jacques: A személy jogai, a politikai humanizmus. In Frivaldszky János (szerk.): Természetjog, szöveggyüjtemény. Budapest, Szent István Társulat, 2006.

Mazzocato, Giuseppe: L'indirizzo personalista ed i suoi problemi. In Angelini, Giuseppe (szerk.): La legge naturale. I principi dell’umano e la molteplicità delle culture. Milánó, Glossa, 2007.

Messinese, Leonardo: La concezione della legge naturale in Jacques Maritain. In Gerardi, Renzo (szerk.): La legge morale naturale, problemi e prospettive. Róma, Pontificia Università Lateranense, 2007.

Mori, Maurizio: Il feto ha diritto alla vita? Un'analisi filosofica dei vari argomenti in materia con particolare riguardo a quello di potenzialità. In Vallauri, Luigi Lombardi (szerk.): Il meritevole di tutela. Milánó, Giuffrè, 1990. 735-839.

Navarini, Claudia (szerk.): Autonomia e autodeterminazione. Profili etici, bioetici e giuridici. Róma, Editori Riuniti University Press, 2011.

Navratyil Zoltán: A varázsló eltöri pálcáját? A jogi szabályozás vonulata az asszisztált humán reprodukciótól a reproduktív klónozásig. Budapest, Gondolat, 2012.

O’Rourke, Kevin D.: The Embryo as Person. The National Catholic Bioethics Quarterly, 6. (2006), 2. 241-251. DOI: https://doi.org/10.5840/ncbq20066249

Pizzorni, Reginaldo: Diritto naturale e diritto positivo in S. Tommaso d'Aquino. Bologna, Studio Domenicano, 1999.

Possenti, Vittorio: Il principio-persona. Róma, Armando, 2006.

Pozzoli, Lafayette: Maritain e o Direito. São Paulo, Loyola, 2001.

Revoredo, Oscar A.: A genderideológia: veszélyek és lehetőségek. Embertárs, (2008) 1. 11-23.

Rodotà, Stefano: La vita e le regole. Tra diritto e non diritto. Milánó, Feltrinelli, 2009.

Sandel, Michael J.: Embryo Ethics: The Moral Logic of Stem-Cell Research. The New England Journal of Medicine, 351. (2004), 3. 207-209. DOI: https://doi.org/10.1056/NEJMp048145

Sandel, Michael J.: Contro la perfezione. L'etica nell'età dell'ingegneria genetica. Milánó, Vita e pensiero, 2014.

Sanguineti, Juan J.: Soul and Person Commentary on «Your Soul is a Distributed Property of the Brains of Yourself and Others» by Michael A. Arbib. Italian Journal of Cognitive Sciences, 2. (2016), 243-252.

Scandroglio, Tommaso: La teoria neoclassica sulla legge naturale di Germain Grisez e John Finnis. Torino, Giappichelli, 2012.

Seifert, Josef: Essere e persona. Verso una fondazione fenomenologica di una metafisica classica e personalistica. Milánó, Vita e pensiero, 1989.

Seifert, Josef: Essere e persona I fondamenti filosofici del personalismo. Philosophical News, 2014. november 9. Elérhető: https://www.philosophicalnews.com/wp-content/uploads/2017/07/9.10. pdf (A letöltés dátuma: 2020. 10. 02.)

Severino, Emanuele: Nascere e altri problemi della coscienza religiosa. Milánó, Rizzoli, 2005.

Severino, Emanuele: Sull'embrione. Milánó, Rizzoli, 2005.

Singer, Peter: Animal Liberation. London, Pimlico, 1995.

Slote, Michael: The Ethics of Care and Empathy. Abingdon, Routledge, 2008. DOI: https://doi. org/10.4324/9780203945735

Spaemann, Robert: Az emberi természet fogalmáról. In Michalski, Krzysztof (szerk.): A modern tudományok emberképe. Budapest, Gondolat, 1988.

Spaemann, Robert: Christianity and Western Philosophy. In Vöneky, Silja - Wolfrum, Rüdiger (szerk.): Human Dignity and Human Cloning. Leiden-Boston, Martinus Nijhoff, 2004. 47-51. DOI: https://doi.org/10.1007/978-94-017-6174-1_5 
Az ember jogalanyiságának, életéhez és méltóságához való joga...

Spaemann, Robert: Persone. Sulla differenza tra „qualcosa” e „qualcuno”. Róma-Bari, Laterza, 2005. Spaemann, Robert: Tre lezioni sulla dignità della vita umana. Torino, Lindau, 2018.

Turgonyi Zoltán: A marxizmus tomista szemmel. In Frenyó Zoltán - Turgonyi Zoltán: Jacques Maritain. Budapest, L'Harmattan, 2006. 55-97.

Vincenti, Umberto: Diritto senza identità, la crisi delle categorie giuridiche tradizionali. RómaBari, Laterza, 2007.

Villey, Michel: Il diritto e i diritti dell'uomo. Siena, Cantagalli, 2009.

Viola, Francesco: La conoscenza della legge naturale nel pensiero di Jacques Maritain. In Maritain, Jacques: Nove lezioni sulla legge naturale. Milánó, Jaca, 1985.

Viola, Francesco: Diritti dell'uomo, diritto naturale, etica contemporanea. Torino, G. Giappichelli, 1989.

Viola, Francesco: I diritti umani: una nuova forma di diritto naturale? In Angelini, Giuseppe (szerk.): La legge naturale, I principi dell'umano e la molteplicità delle culture. Milánó, Glossa, 2007. 137-149.

Waldstein, Wolfgang: A szivébe írva. A természetjog mint az emberi társadalom alapja. Budapest, Szent István Társulat, 2012. 